\title{
Article \\ Evolution of Solar Energy in Chile: Residential Opportunities in Arica and Parinacota
}

\author{
Claudia Moraga-Contreras 1,*, Lorena Cornejo-Ponce ${ }^{2,3}$ (D) Patricia Vilca-Salinas $2,3 \oplus$, Edgar Estupiñan ${ }^{2}$, \\ Alejandro Zuñiga ${ }^{4}$, Rodrigo Palma-Behnke ${ }^{5}$ (i) and Héctor Tapia-Caroca ${ }^{3}$ (i)
}

Citation: Moraga-Contreras, C.; Cornejo-Ponce, L.; Vilca-Salinas, P.;

Estupiñan, E.; Zuñiga, A.;

Palma-Behnke, R.; Tapia-Caroca, H. Evolution of Solar Energy in Chile: Residential Opportunities in Arica and Parinacota. Energies 2022, 15, 551. https://doi.org/10.3390/en15020551

Academic Editors: Nicu Bizon, Mihai Oproescu, Philippe Poure, Rocío Pérez de Prado and Abdessattar Abdelkefi

Received: 31 October 2021 Accepted: 9 January 2022 Published: 13 January 2022

Publisher's Note: MDPI stays neutral with regard to jurisdictional claims in published maps and institutional affiliations.

Copyright: (C) 2022 by the authors. Licensee MDPI, Basel, Switzerland. This article is an open access article distributed under the terms and conditions of the Creative Commons Attribution (CC BY) license (https:// creativecommons.org/licenses/by/ $4.0 /)$.
1 Escuela de Derecho, Facultad de Ciencias Sociales y Jurídicas, Universidad de Tarapacá, Arica 1100000, Chile

2 Departamento de Ingeniería Mecánica, Facultad de Ingeniería, Universidad de Tarapacá, Arica 1100000, Chile; lorenacp@academicos.uta.cl (L.C.-P.); patricia786vilca@yahoo.es (P.V.-S.); eestupin@academicos.uta.cl (E.E.)

3 Laboratorio de Investigaciones Medioambientales de Zonas Áridas, LIMZA, Universidad de Tarapacá, Arica 1100000, Chile; hectortapiacaroca@gmail.com

4 Departamento Jurídico, Servicio de Vivienda y Urbanismo, SERVIU, Arica 1100000, Chile; alejandrozuniga1977@gmail.cl

5 Centro de Energía, Departamento de Ingeniería Eléctrica, FCFM, Universidad de Chile, Santiago 7500000, Chile; rrodpalma@gmail.com

* Correspondence: cmoragac@academicos.uta.cl; Tel.: +56-58-2205974

\begin{abstract}
Chile has set itself to achieve Greenhouse Gas emission neutrality, with at least $70 \%$ of electricity coming from renewable energy sources by 2050. To this end, institutional and regulatory frameworks have been improved, resulting in significant progress in medium and large-scale projects. However, solar energy production at residential level and its surplus injection to all distribution networks has been very limited. This paper analyzes the evolution of the regulatory energy policies in Chile in order to contrast it with an economic evaluation of residential projects. The analysis focuses on the city of Arica, one of the highest potential regions in terms of solar energy within the country. There, a particularly low penetration of residential solar energy usage has been observed. Based on the current situation, projections are made for Arica in 2050, through the identification of barriers and opportunities on a residential scale development. According to some recommendations, there is the need to design policies that take into account the particular characteristics of each region within the country.
\end{abstract}

Keywords: distributed generation; energy policy; solar energy

\section{Introduction}

Electric power is sometimes central to some aspects of societal development [1]. However, 840 million people living in rural areas lack this essential service [2]. According to the World Bank, as of 2015,87.06\% of the world's population had access to electricity, $65.24 \%$ of which was supplied from fossil sources such as oil, gas or coal [3]. All said fuels are great contributors of carbon dioxide production $\left(\mathrm{CO}_{2}\right)$, which is considered the main environmental pollutant. By 2040, emissions are estimated to reach 43.2 billion metric tons [4]. In accordance with the requirements of the Paris Agreement, Chile has initiated a decarbonization process, committing to Greenhouse Gas (GHG) emissions neutrality by 2050 [5]. In May 2014, the Energy Agenda was approved by Ministerio de Energía (Chilean Ministry of Energy, Santiago, Chile, 2014), with the objective of promoting the development of Non-Conventional Renewable Energies (NCRE, which includes all renewable energies, excluding hydroelectric plants larger than $20 \mathrm{MW}$ of installed capacity) and designing the first version of the Long-Term Energy Policy [6]. This proposal states that at least $70 \%$ of electricity should be generated from renewable sources, GHG emissions should be reduced and that no region should have more than one hour of average unavailability of electricity supply per year. These are urgent issues to be addressed, especially because Chile has a growing energy demand that cannot be met with local energy, importing $60 \%$ of its primary energy requirements [7]. 
Among some measures aimed at meeting the growing energy demand, there are laws that seek to promote residential electricity generation through non-conventional renewable energies [8,9].

Recently, PV, CSP (Concentrated Solar Power) and wind energy have had considerable growth in Chile, surpassing other NCRE, such as hydro, biomass and geothermal. Figure 1 presents monthly data considering the injection of the different technologies between October 2012 and October 2021 [10].

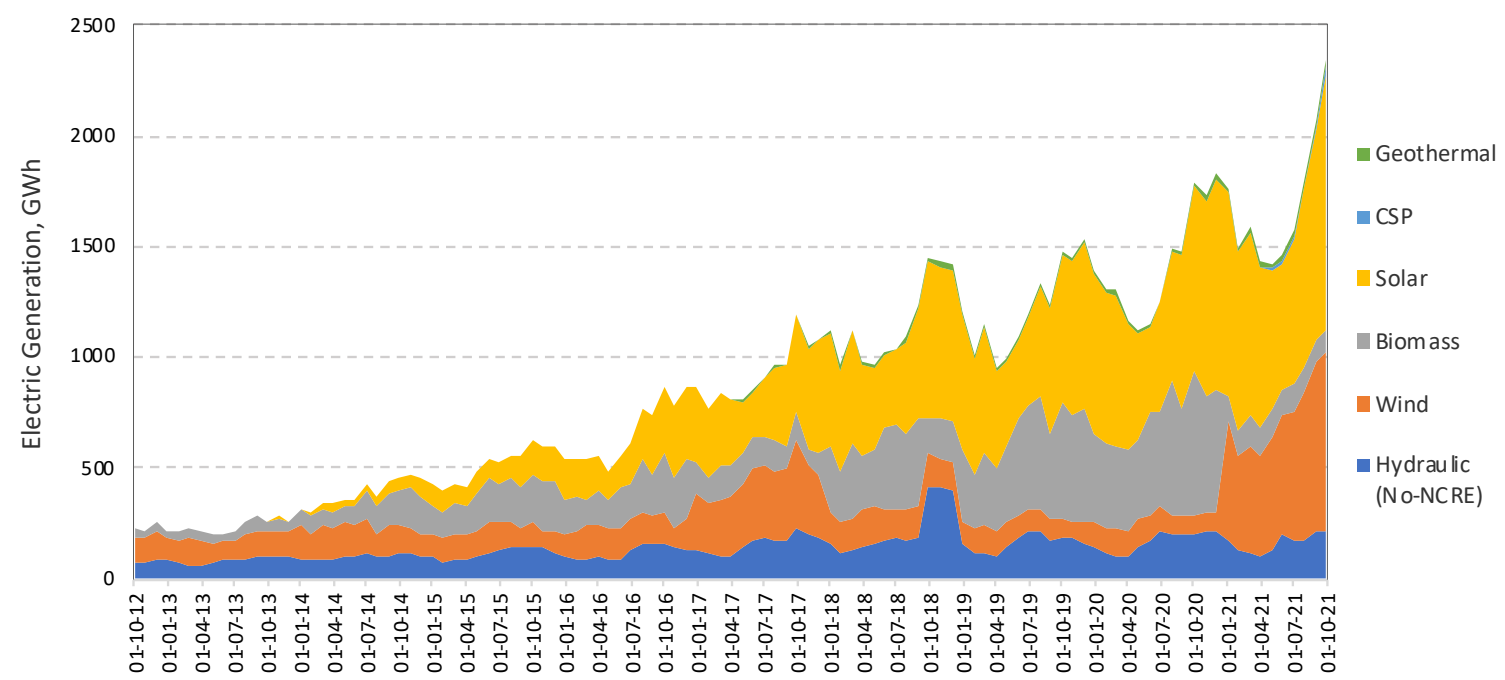

Date

Figure 1. Monthly electricity generation, obtained from NCRE in Chile (2012-2021), Source: Energía Abierta, 2021 [10].

Chile is a worldwide privileged country in terms of solar energy. This is especially true for the Atacama Desert located in the north of the country, as it has one of the best conditions for the installation and development of solar technologies in the globe. The average Direct Solar Radiation of $2506 \mathrm{kWh} / \mathrm{m}^{2}$ per year [11] is greater than that of Spain, Abu Dhabi, USA, among other countries with high presence of solar installations (Figure 2). This condition and its potentialities have been explored since the installment of the first solar desalination plant: Las Salinas saltpeter office in 1872 [12], with a distillate production of $5000 \mathrm{~m}^{2}$ through $2 \mathrm{MWt}$ [13].

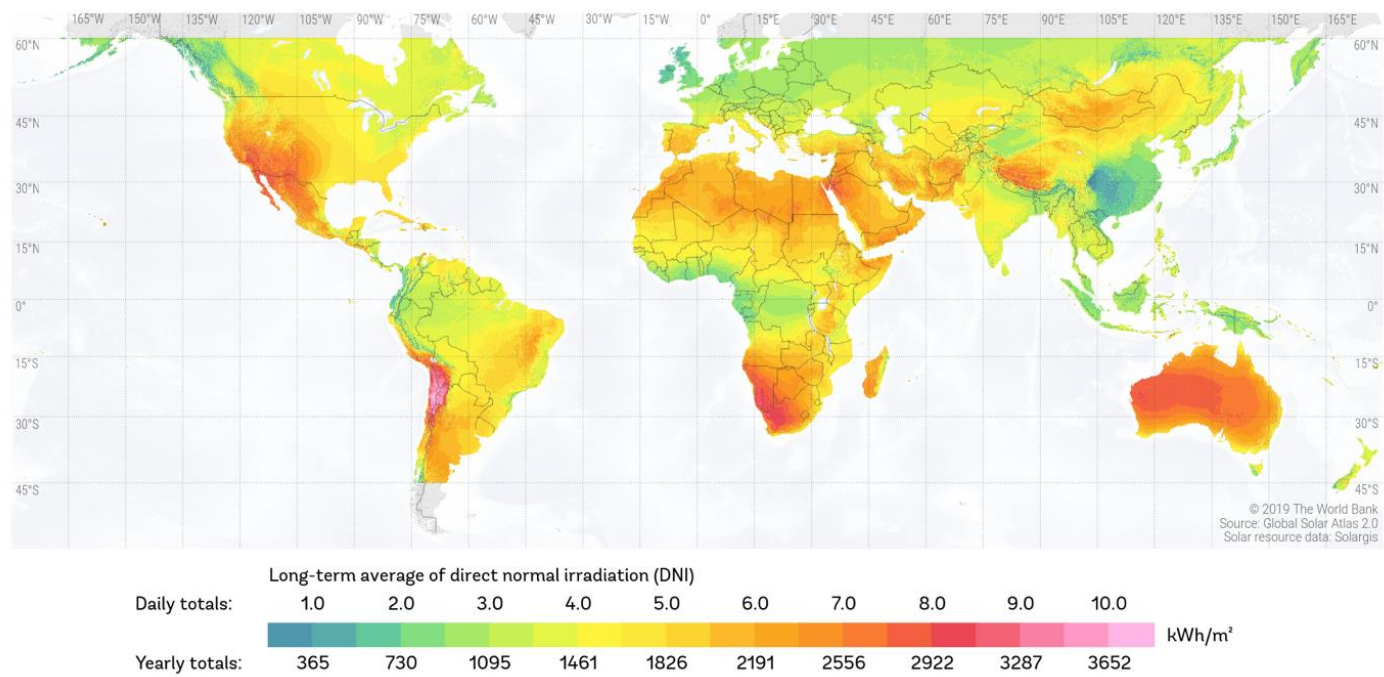

Figure 2. Map of Direct Normal Irradiation [14] 
In Chile, solar energy is strongly developing since 2012 (Table 1), adding more than $4000 \mathrm{MW}$ of energy by mid-2021 and more than 40,000 MW in already approved and under construction projects [15].

Table 1. Status of NCRE projects in Chile [15].

\begin{tabular}{cccc}
\hline Technology & $\begin{array}{c}\text { Operation (1) } \\
\text { (MW) }\end{array}$ & $\begin{array}{c}\text { Construction } \\
\text { (MW) }\end{array}$ & $\begin{array}{c}\text { RCA Approved (2) } \\
\text { (MW) }\end{array}$ \\
\hline Biomass (3) & 416 & 166 & 0 \\
\hline Wind & 2492 & 1176 & 11,286 \\
\hline Geothermal & 40 & 0 & 755 \\
\hline Mini-Hydro (4) & 612 & 53 & 26,525 \\
\hline PV & 3777 & 3338 & 2032 \\
\hline CSP & 0 & 0 & 40,749
\end{tabular}

(1) Considers only commercial operation delivered projects; (2) Considers all projects approved to date; (3) Considers biogas projects; (4) Represents run-of-river hydroelectric plants with installed capacity of less than $20 \mathrm{MW}$.

The region of Arica and Parinacota is located in the extreme north of Chile, with an area of $16,873 \mathrm{~km}^{2}$ and a population of 258,778 inhabitants. While in 2012 the region had 66,370 dwellings, in 2017 they already amounted to 76,201 [16]. The average residential electricity consumption per customer was $181 \mathrm{kWh} /$ year [17], which places it within the regions with the highest demand of residential electricity.

On the other hand, the economic evaluation of the installation of a solar generation system is very important, since it will determine if the project is convenient and economically viable or not. In this publication, the System Advisor Model (SAM) was used, a program that has been developed by the National Renewable Energy Laboratory (NREL), in collaboration with Sandia National Laboratories, US Department of Energy (DOE) and Solar Energy Technologies Program (SETP). SAM can make performance predictions and energy cost estimates for grid-connected power based on installation and operating costs, and system design parameters that can be specified as inputs to the model (financial and management model) [18]. Among these models, the following can be found: photovoltaics (flat-plate and concentrating), concentrating solar power (parabolic troughs, towers, linear Fresnel, dish-Stirling), solar water heating, wind, geothermal, and biomass [19]. SAM's financial models calculate financial metrics for various types of energy projects based on the cash flows of a project during a specified analysis period, and uses the electrical output of the system calculated by the performance model to calculate the series of annual cash flows.

Therefore, this paper analyzes the effectiveness of Chilean laws in promoting the usage of non-conventional renewable energies at residential level and their surplus injection into the distribution system. It emphasizes the utilization of solar energy in the city of Arica, with a projection to the year 2050. Chilean energy agenda is taken into account.

Obtained results aspire to constitute a contribution to the existing literature, by providing an overview on the evolution of public policies at national level in relation to the energy sector. Generation of electricity from NCRE proposed by Law No. 20571 [20], especially solar energy, is evaluated; identifying the number of homes and companies that have invoked the laws under study in the region of Arica and Parinacota. Real effects of the injection of energy into the electricity distribution system in the city of Arica has also been evaluated, as well as the projection of its application to 2050 . We believe that, within the main contributions of this work, is to reveal that the laws, regulations and public policies implemented in the field of distributed generation, require taking into account the geographical areas in which they intend to be implemented, with a focus on people and their needs.

Considering the above, the manuscript is organized in six sections, starting with a description of the topic related to the evolution of solar energy in Chile (opportunities at 
residential level), the Section 2 presents the methodology used to perform an analysis of the political-legal system of regulations in Chile related to the use of solar photovoltaic energy for residential electricity generation. The Section 3 discusses the installed capacity of solar photovoltaic energy in the world and in Chile, indicating the production potential, costs and implementation of solar energy in the city of Arica. In Section 4, a case study is conducted for the city of Arica. In Section 5, a projection for the year 2050 in the same city is presented and finally in Section 6, a discussion of the results obtained and conclusions are made.

\section{Methodology}

As indicated in Section 1, the methodology used has a set of analysis schemes detailed below. In Section 2, the dogmatic method is used to analyze and categorize the set of regulations that make up an integral system aimed at stimulating energy generation through non-conventional renewable sources. Section 3 presents information regarding statistics and analysis of worldwide installed capacity, Chile and the region of Arica and Parinacota, considering aspects such as: costs, energy conditions, distributed generation, among others. In Section 4, a case study is carried out for the city of Arica (Region of Arica and Parinacota-Chile), to evaluate and project its electricity consumption for the next 30 years. This method favors in-depth behavioral analysis of electric energy users, allowing to showcase its main requirements and how, consequently, it can impact the utilization of solar energy in the city of Arica. Finally, in Section 5, through this documentary study it will be possible to identify barriers and opportunities (Figure 3) related to the effect produced in the population by laws on the subject (Law No. 20571). To accomplish it, statistics on electricity consumption of a sector of the total population have been obtained and analyzed and paired with knowledge of the fundamental facts related to the research. Likewise, software Explorador Solar [21], System Advisor Model, SAM [18] and the projection based on the Long-Range Energy Alternatives Planning System, LEAP [22] are used to project electricity consumption of Arica, Chile, up to the year 2050.

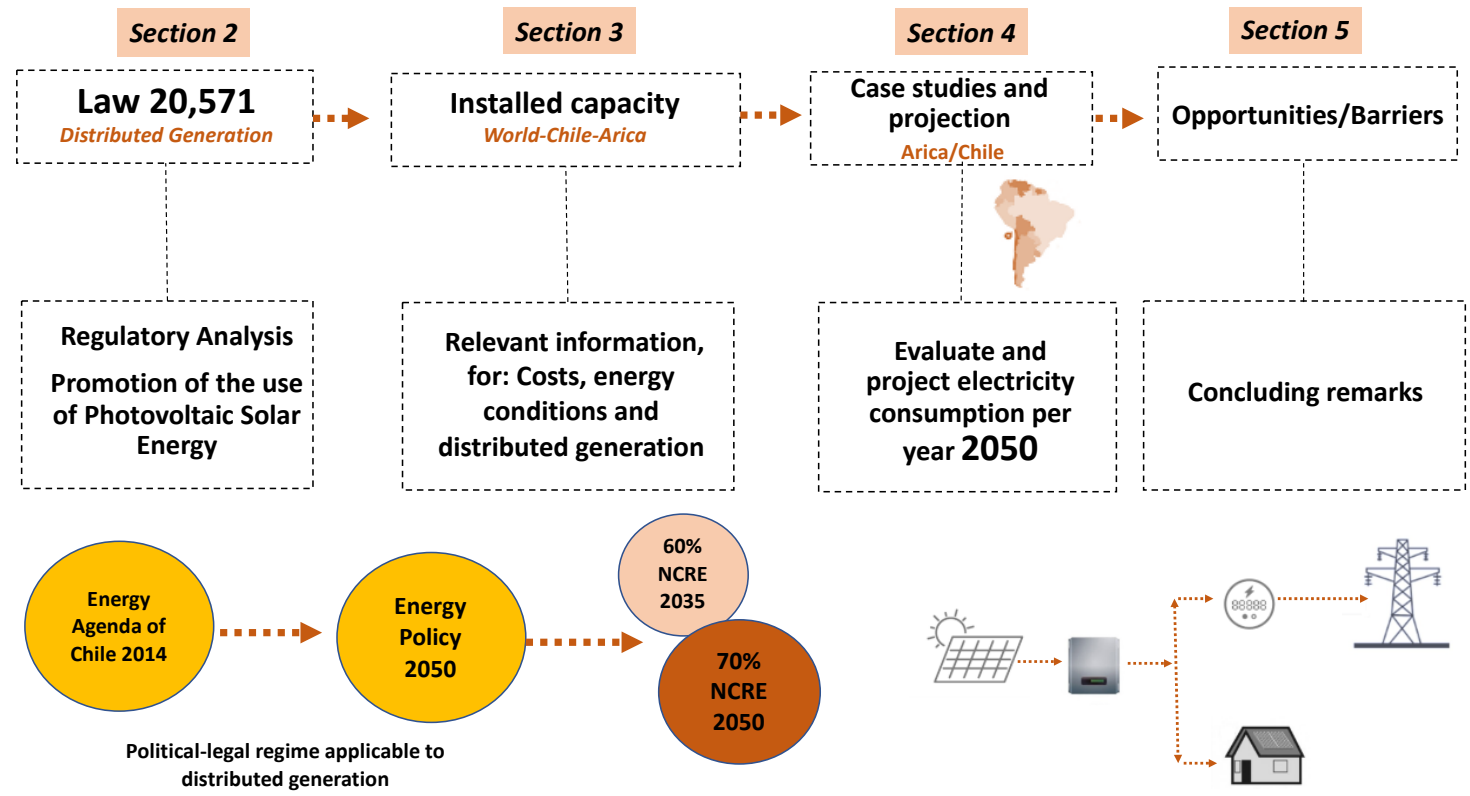

Figure 3. Applied methodology. Source: Prepared by the authors.

\section{Residential Level NCRE Promoting Regulations}

According to the Global Climate Risk Index report [23], Chile stands among the 10 most affected nations by this phenomenon as a result of the meteorological events recorded in 2015. A flood affected the province of Chañaral, in the Atacama region [24], which, along with other factors, stimulated the use of NCRE in the sector for electricity self-consumption by means of reducing vulnerability on the area and minimizing its environmental impact. 
Among initiatives included in this energy policy is the implementation of Distributed Generation, understood in general terms as a small source of electricity generation, up to $10 \mathrm{MW}$, which is connected directly to the distribution network or secondary transmission network [25]. It is also self-generated by a regulated customer. In the case of Chile, the limit is $9 \mathrm{MW}$, while at the residential level the limit considered is $300 \mathrm{~kW} \mathrm{[26].}$

The installation of electrical grids based on Distributed Generation reduces GHG emissions (mainly $\mathrm{CO}_{2}$ ) considering the use of renewable energy sources. In times of higher energy demand, it functions as a very useful backup, decreasing electricity consumption to large power plants or injecting the surplus to said plants, favoring the reduction of transmission and distribution system requirements of ohmic power losses [27]. However, if a good sizing of the Distributed Generation systems installations is not performed, their massive integration can cause problems in voltage regulation and losses, poor power quality, high failure level, low reliability, among other predicaments [25].

\subsection{Political-Legal Regime Applicable to Distributed Generation in Chile}

Laws and public policies are essential in order to stimulate those behaviors that a State deems as a priority based on strategic, coherent and situated definitions. This section analyzes laws and policies related to distributed generation, their drawbacks and virtues in order to assess their effectiveness and contribute to the main objective of this study.

Energy Policy towards 2050

The Chilean Energy Agenda of 2014 [28] contemplates aspects that should be considered in the electricity sector in order to have reliable, sustainable, inclusive and reasonably priced energy. Among its goals and objectives, the Agenda considered promoting the development of NCRE to meet the 20\% target by 2025 [29] (Law No. 20698). All this by propelling the efficient use of energy, through the following actions:

- $\quad$ Lifting existing barriers for NCRE in the country. $45 \%$ of the electricity generation capacity to be installed in the country between 2014 and 2025 will come from this type of source.

- $\quad$ Promoting efficient use of energy as an energy resource, establishing a savings goal of $20 \%$ by 2025.

- $\quad$ Developing a long-term Energy Policy, validated by Chilean society, through a participatory and regional process, among others.

In addition, it proposes a new role for the State, allowing the establishment of a social, political and technical dialogue that incorporates regional realities and visions of the various actors of society with a short-term horizon of 2025 and a long-term horizon of 2050. Likewise, the development of self-generated energy resources is proposed, in order to stimulate the integration of NCRE. This stimulation should be in compliance with the NCRE Promotion Law (20/25); to promote the development of a socially efficient NCRE market for self-consumption and transversal to all economic actors. Finally, the development, together with regions and communes, of specialized plans for extreme or isolated areas. Promotion of the use of photovoltaic energy is sought and it is announced that the "Public Solar Roofs Program" [30], which will contribute to the maturation of the photovoltaic market oriented to self-consumption, will be launched.

The Chilean Energy Policy proposes a vision of the energy sector to 2050 that positions it as a reliable, sustainable, inclusive and competitive sector. On the one hand, this vision follows a systemic approach. Its main objective is to achieve and maintain the reliability of the entire energy system while complying with sustainability and inclusion criteria and contributing to the competitiveness of the country's economy in order to move towards sustainable energy in all its dimensions. On the other hand, the Energy Policy remarks that Chile is positioned among the three OECD countries with lowest average prices of electricity supply in the long term at residential and industrial level [6] as a fundamental condition in order to achieve sustainable development.

In the search for alternative energy sources, as well as the minimization of dependence on other countries to satisfy domestic consumption, Chile has been oriented to seeking non- 
conventional energy generation sources. In accordance to the latter, the Energy Policy objective is to implement all necessary measures to ensure that renewable energies constitute $60 \%$ by 2035, and at least $70 \%$ by 2050, considering the goals described in Figure 4.

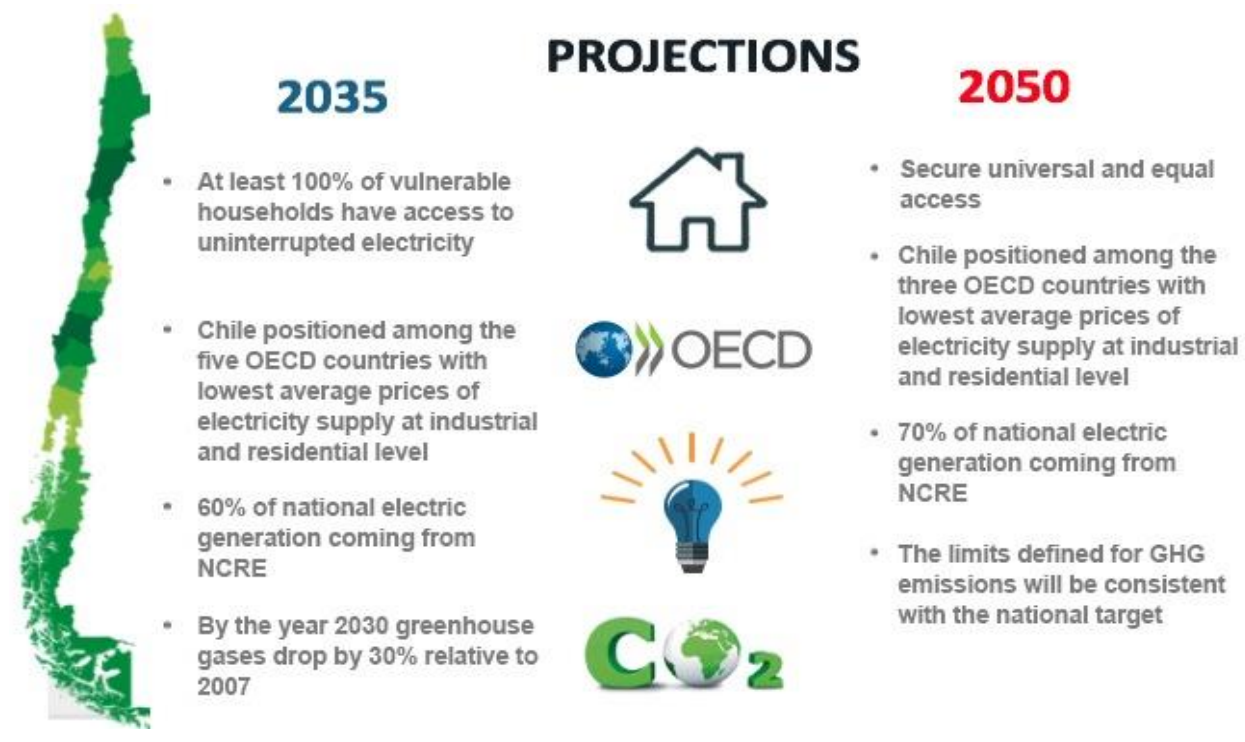

Figure 4. Necessary measurements for electric generation resulting from renewable energies 2035 and 2050. Source: [6].

\subsection{Payment of Electricity Tariffs of Residential Generators}

The interest in legally encouraging distributed generation in Chile is relatively new. It was not until 2008 that a bill on discounting and payment of electricity tariffs to residential generators was discussed. Thus, in order to grant regulated customers, the right to generate their own electricity, consume it and sell their surplus energy to electricity distribution companies [31].

On 20 February 2012, after 4 years of debate and deliberation, Law No. 20571 was enacted to regulate the payment of electricity tariffs for residential generators.

\subsection{Main Provisions of Law No. 20571}

Law No. 20571 [32] introduced a series of amendments to Ley General de Servicios Eléctricos (General Law of Electric Services), providing special tariff rules for end users subject to pricing who have their own electric energy equipment by non-conventional renewable means, i.e., by all renewable energy sources with the exception of hydroelectric plants with installed capacity exceeding $20 \mathrm{MW}$ or that have efficient cogeneration facilities.

Therefore, end users subject to pricing that have their own electric energy equipment by non-conventional renewable means, or efficient cogeneration facilities, will have the right to inject the energy they generate into the distribution network through respective connections, ordering the enactment of a regulation in which the requirements are determined. The regulation will determine all compliances of the equipment: requirements, safety measures and technical specifications as to carry out the injections and the installed capacity allowed for each end user, which may not exceed $100 \mathrm{~kW}$ (value that as from November 2020 will be increased to $300 \mathrm{~kW}$ ). This measure will obligate the concessionaire of the public distribution service to ensure compliance with these requirements.

The law gave jurisdiction to the Superintendencia de Electricidad y CombustiblesSEC (Superintendency of Electricity and Fuels) to oversee compliance with these rules and to hear and resolve claims and disputes between the public distribution service concessionaire and end users who make or wish to make use of their right to inject surplus energy.

Finally, the law guaranteed a procedure to opt for the benefits above and determined the forms of valuation, discounts or payments that must be made from the invoicing in relation to the injection of energy into the system. 


\subsection{Main Provisions of Law No. 21118 and Its Regulations}

Only 4 years after the entry of Law No. 20571, Law No. 21118 [33] was enacted, which again modifies the Ley General de Servicios Eléctricos (General Law of Electric Services) with the purpose of effectively encouraging, the only partially achieved, development of residential generators.

On the one hand, among the main innovations of this law is the right of end users to: install generators individually or collectively and increase the installed capacity of a client from $100 \mathrm{~kW}$ to $300 \mathrm{~kW}$. It also offered a regulation on the payment of the remaining injections by the distribution companies to the users; and the duty of the Ministerio de Energía to evaluate the implementation and application of the law. Said evaluation was made in relation to the increase or decrease of end users that count with their own nonconventional renewable equipment or efficient cogeneration facilities.

The regulation of Law No. 21118, on the other hand, provided that injections of electric energy made by the end users that count with Generation Equipment, will be valued at the node price of energy that must be transfer monthly to their final customers by Distribution Companies, subject to price regulation, incorporating lower electric losses of the Distribution Company associated to these energy injections. All energy injections shall be discounted from Electricity Supply Charges of the billing corresponding to the month in which such injections were made. Should there be a remainder in favor of the Customer or End User, it shall be charged and discounted in the subsequent invoice or invoices.

To be considered, these conditions contrast with the international experience, particularly in Europe, where net-metering or feed-in-tariff schemes are favored.

Laws, regulations and public policies implemented in Chile in recent years regarding distributed generation have ignored the fact that, although the country has clear advantages in terms of NCRE availability; especially solar energy in certain geographical areas of the country, the main objective is to propel energy generation at residential level. However, the focus on people and their needs was nowhere to be found. Nothing is said regarding the promotion and dissemination of the law, the creation of incentives or preferential credits to access complex generation systems with high technical requirements. Furthermore, the initial investment cost involved in the installation of NCRE energy generation systems. To be noted, the installation of photovoltaic panels corresponds to approximately 2500 dollars to meet the average electricity consumption of a household of $180 \mathrm{kWh}$ per month.

\section{Installed Capacity of Solar Photovoltaic Energy in the World and Chile}

As a consequence of greater heating and cooling demand and the need for a more robust economy, the world energy demand increased by approximately $2.3 \%$ in 2018 , being the highest growth since 2010 [34]. Part of this demand has been sustained by renewable energy for several years, considering that its global production at the end of 2018 corresponded to $26 \%$ [35].

Solar photovoltaic energy is the third technology with the highest cumulative installed capacity in the world, reaching a maximum of 709,674 MW in 2020. In the first place, renewable hydroelectric energy stands at 1,154,313 MW [36] and in the second, wind energy at 698,043 MW.

Currently, Chile has an installed generation capacity of around 28,000 MW. 65.0\% comes from conventional electric energy sources (coal, natural gas, diesel oil, hydropower greater than $20 \mathrm{MW}$ ) and $35.0 \%$ corresponds to energy obtained from NCRE, PV, wind, biomass and geothermal energy [37].

Briefly, solar photovoltaic technology reached $4000 \mathrm{MW}$ in 2021 (13\% of the total installed capacity), while in the region of Arica and Parinacota its development is only $8 \mathrm{MW}$ [17], corresponding to the third region with the lowest production at national level and representing a minuscule piece worldwide (Table 2). However, as a percentage of the installed capacity in the region ( $32 \mathrm{MW}$ ), it represents a significant penetration percentage close to $25 \%$, which exceeds $50 \%$ if the installed hydraulic capacity of $10 \mathrm{MW}$ is added. 
Table 2. Chilean regional statistics related to solar energy consumption, 2021 [38].

\begin{tabular}{|c|c|c|c|c|c|c|c|c|c|}
\hline Region & $\begin{array}{c}\text { Surface Area } \\
\left(\mathbf{k m}^{2}\right)\end{array}$ & $\begin{array}{l}\text { Population } \\
\text { (Inhabitants) }\end{array}$ & $\begin{array}{c}\text { Number of } \\
\text { Regulated } \\
\text { Clients }\end{array}$ & $\begin{array}{c}\text { Electric } \\
\text { Residential } \\
\text { Consumption } \\
\text { per Client } \\
\text { (kWh/month) }\end{array}$ & $\begin{array}{c}\text { Installed } \\
\text { Photovoltaic } \\
\text { Solar Capacity } \\
\text { (MW) }\end{array}$ & $\begin{array}{c}\text { Gross } \\
\text { Photovoltaic } \\
\text { Electric } \\
\text { Generation } \\
\text { (GWh) }\end{array}$ & $\begin{array}{c}\text { Public Solar } \\
\text { Roofs Total } \\
\text { Capacity } \\
\text { (kW) }\end{array}$ & $\begin{array}{c}\text { Monthly Tariff } \\
\text { BT1 } \\
\text { (Estimated } \\
\text { Consumption } \\
\text { of } 180 \mathrm{kWh} \text { ) } \\
\text { (USD) }\end{array}$ & $\begin{array}{l}\text { Distributed } \\
\text { Generation by } \\
\text { Law } \\
(\mathbf{k W})\end{array}$ \\
\hline $\begin{array}{c}\text { Arica y } \\
\text { Parinacota }\end{array}$ & 16,873 & 252,110 & 81,214 & 176 & 8 & 1.45 & 200 & 28.9 & 657 \\
\hline Tarapacá & 42,226 & 382,773 & 111,478 & 183.1 & 415.83 & 72.96 & 365 & 28.4 & 664 \\
\hline Atacama & 75,176 & 314,709 & 110,300 & 149.8 & 1302.46 & 169.83 & 512 & 29.0 & 3422 \\
\hline Coquimbo & 40,580 & 836,096 & 336,665 & 136.4 & 297.48 & 36.09 & 325 & 30.3 & 7850 \\
\hline Metropolitana & 15,403 & $8,125,072$ & $2,660,897$ & 197.3 & 395.60 & 35.41 & 1225 & 24.3 & 27,434 \\
\hline Valparaíso & 16,396 & $1,960,170$ & 883,511 & 147.2 & 185.42 & 17.44 & 325 & 30.2 & 13,355 \\
\hline $\begin{array}{l}\text { Libertador B. } \\
\text { O'Higgins }\end{array}$ & 16,387 & 991,063 & 389,821 & 155.1 & 231.56 & 27.95 & 500 & 27.0 & 15,103 \\
\hline Nuble & 13,179 & 491,204 & 223,030 & 0 & 62.01 & 2.94 & 115 & 30.4 & 2975 \\
\hline Maule & 30,269 & $1,131,939$ & 482,187 & 137.2 & 158.96 & 8.69 & 830 & 29.1 & 12,646 \\
\hline Bío Bío & 23,890 & $1,663,696$ & 639,565 & 142.3 & 13.98 & 0 & 300 & 30.0 & 3834 \\
\hline
\end{tabular}




\subsection{Cost of Electricity Worldwide}

Worldwide (Figure 5), Denmark (0.358 USD/kWh) and Germany (0.345 USD/kWh) account for the highest electricity tariffs for residential use. In South America, Uruguay has the highest tariff (0.296 USD/kWh), followed by Chile ( $0.158 \mathrm{USD} / \mathrm{kWh})$, while Bolivia and Argentina have the lowest electricity tariffs for residential use $(0.075 \mathrm{USD} / \mathrm{kWh}$ and $0.058 \mathrm{USD} / \mathrm{kWh}$, respectively).

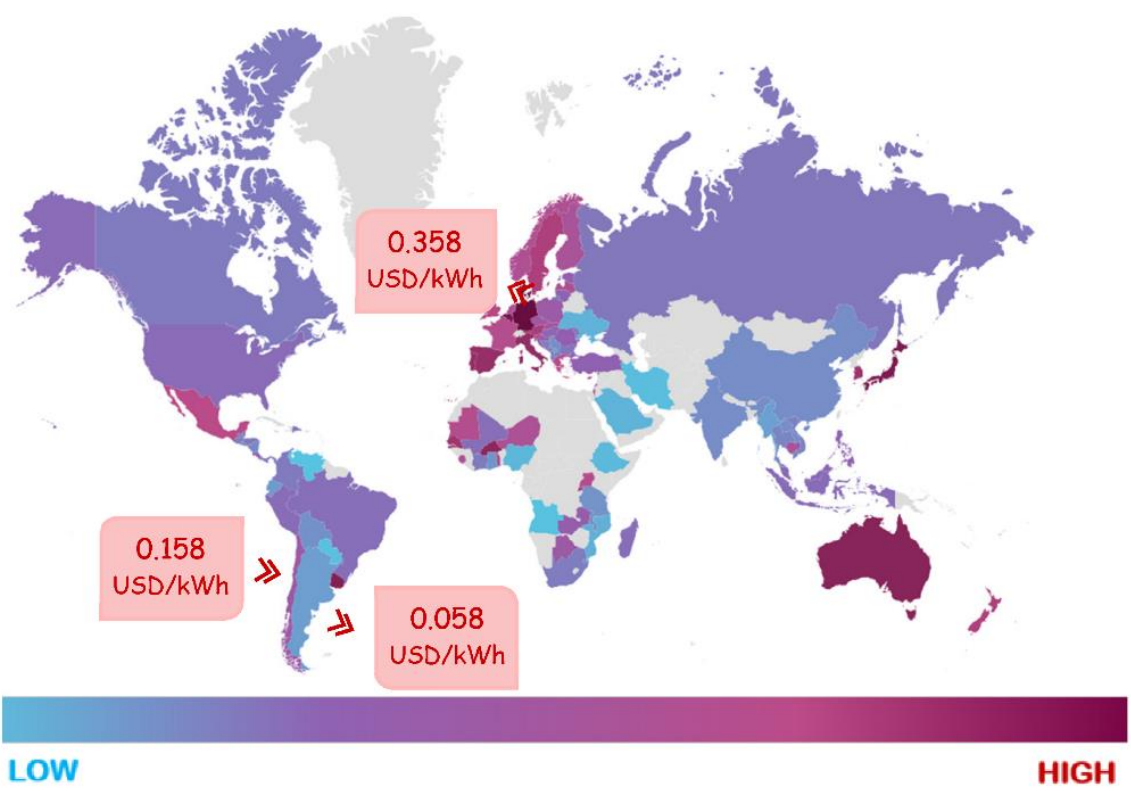

Figure 5. World map: electric tariffs for residential use (USD/kWh) [39].

\subsection{Facilities Declared before the SEC at National Level}

In 2015, the first 90 residential installations were declared before the Superintendencia de Electricidad y Combustible (Figure 6) [40], which as of August 2021 amounts to 9008 installations.

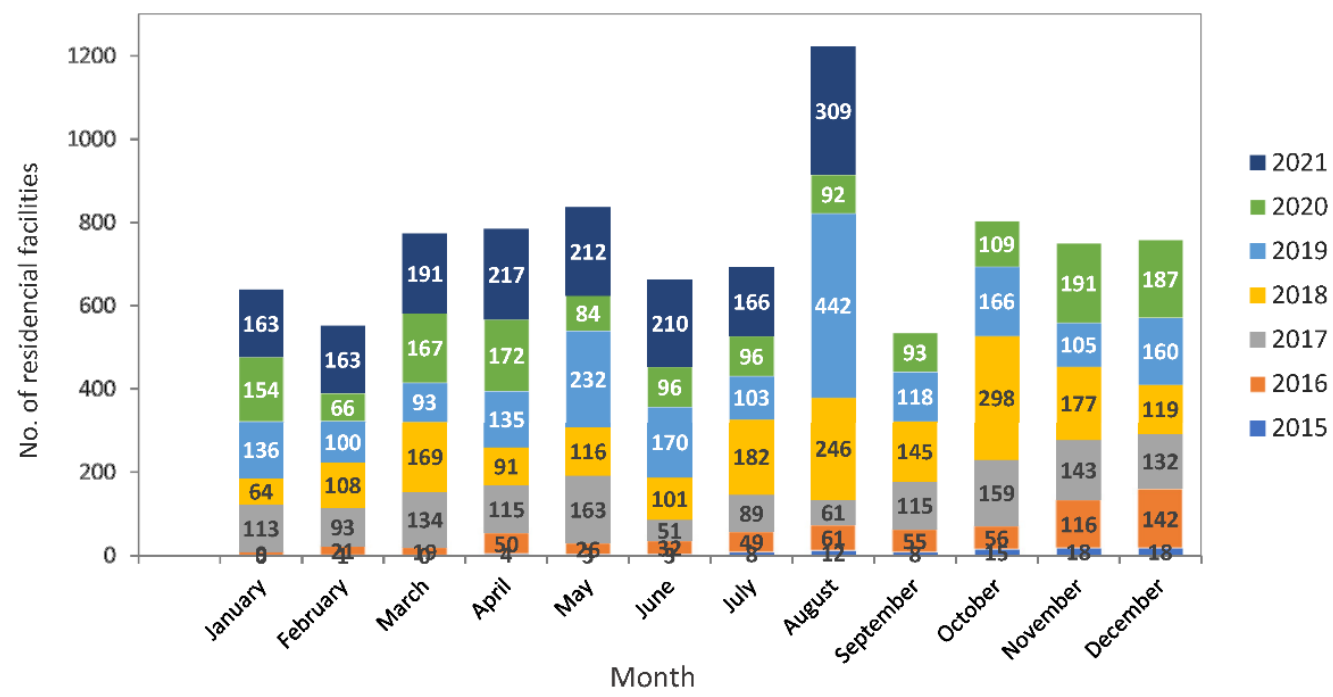

Figure 6. No. of residential facilities declared before the SEC at national level according to Law No. 20571 years 2015-2021. Source: [40]. 


\subsection{Solar Radiation Conditions in the City of Arica, Costs, Distributed Generation and Distribution Cases}

\subsubsection{Solar Radiation and Solar Energy Production Capacity}

The sun as a renewable source of energy allows generating photovoltaic or thermal solar energy and within a year reaches $1.52 \times 10^{18} \mathrm{kWh}$ [41]. The Atacama Desert, located in Chile, presents ideal conditions for the use of solar energy, given the irradiation levels it presents; between 7 and $7.5 \mathrm{kWh} /\left(\mathrm{m}^{2}\right.$ day) [42]. Arica city is precisely located in this desert. It presents some of the best energy potentials throughout the country, with an annual radiation of $2957 \mathrm{kWh} / \mathrm{m}^{2}$ [11] and represents a focal point of development and innovation in energy matters. However, this is not yet reflected in regional energy statistics.

\subsubsection{Cost of Electricity}

At the local level, the electricity company that distributes conventional electricity is CGE (EMERLARI), which sets its rates in accordance with the provisions of Ley de Electricidad and Ministerio de Economía (Ministry of Economy). Table 3 shows Tariff B1 (monomic) [43], for which the energy consumed by the client is measured. There is no direct charge for the power demanded. This tariff is available if the customer has a low voltage supply and a connected power of less than $10 \mathrm{~kW}$. This tariff is the most commonly used by residential customers and is composed of the following charges:

- Monthly Fixed Charge: Billed every month of the year, regardless of the customer's consumption.

- $\quad$ Lease Charge: Billed every month to customers who choose to lease metering equipment from the company.

- $\quad$ Base Energy Charge: Obtained by multiplying the monthly energy consumed (kWh) by the unit price of basal energy (USD/kWh).

- Additional Energy Charge: It is applied from April to September, when consumption is higher than $430 \mathrm{kWh}$, and additionally, higher than winter limit.

It is worth noting that residential electricity consumption per customer is $180 \mathrm{kWh} /$ year, and the region is considered to be electricity deficient, reaching an annual electricity interruption time of $18.74 \mathrm{~h} /$ customer [10].

\subsubsection{Distributed Generation in the Region of Arica and Parinacota}

As mentioned above, the region of Arica and Parinacota has one of the best radiation levels in the world, with clear days almost 300 days a year. This region belongs to the northern part of the country. Being a long and narrow strip of land, Chile is divided into four zones, north (Zona norte), center (Zona Centro), south (Zona sur) and austral (extreme south). Each one presents a particular microclimate: desert, temperate, rainy temperate and rainy maritime temperate climates, respectively. Therefore, in the northern zone, days are clear and sunny while as you move south, they form into cloudy and rainy. This particularity of the country, favors the implementation of NCRE, such as solar energy, a condition that is reflected mainly in the regions of the Norte Grande of Chile (Atacama Desert) with a Normal Annual Direct Irradiation of $2957\left(\mathrm{kWh} / \mathrm{m}^{2}\right)$, as mentioned above.

If we compare solar radiation by regions as shown in Figure 7, it can be extracted that the northern (Arica to Coquimbo), central (Metropolitan Region to Maule) and southern (Bíobío) (Figure 7) zones clearly showcase that the maximum Normal Annual Direct Irradiation fluctuates between 3365 and $2957 \mathrm{kWh} / \mathrm{m}^{2} /$ year in the first zone, followed by 2508-2511 kWh $/ \mathrm{m}^{2} /$ year and $2431 \mathrm{kWh} / \mathrm{m}^{2} /$ year in the latter.

The following graph exhibits no direct correlation between solar radiation and the application of the Distributed Generation Law in Chilean regions.

Regarding the applicability of the Ley de Generación Distribuida (Distributed Generation Law), the central zone has $71,513 \mathrm{~kW}$, the northern zone $13,457 \mathrm{~kW}$ and the southern zone $3834 \mathrm{~kW}$ [38].

It is worth analyzing this "incongruence" between sectors with higher solar radiation and those with lower application of Law No. 20571, as in the city of Arica, northern Chile. 
Table 3. BT1 tariff, consumed by residential customers, Source CGE, 2021 [43].

\begin{tabular}{|c|c|c|c|c|c|c|c|c|c|c|c|c|c|}
\hline \multirow{4}{*}{ Commune } & \multirow{4}{*}{$\begin{array}{l}\text { Tariff } \\
\text { Sector }\end{array}$} & \multirow{4}{*}{$\begin{array}{c}\text { Aerial or } \\
\text { Underground }\end{array}$} & \multicolumn{11}{|c|}{ BT1 TARIFF } \\
\hline & & & \multirow{3}{*}{$\begin{array}{c}\begin{array}{c}\text { Service } \\
\text { Administration }\end{array} \\
\text { Fixed Monthly } \\
\text { Charge BT1 } \\
\text { (USD/Client) }\end{array}$} & \multicolumn{2}{|c|}{ Electricity Transport } & \multirow{3}{*}{$\begin{array}{l}\text { Energy Charge } \\
\text { (USD/kWh) }\end{array}$} & \multirow{3}{*}{$\begin{array}{c}\text { Power Purchase } \\
\text { Charge } \\
\text { (USD/kWh) }\end{array}$} & \multicolumn{6}{|c|}{ Consumed Electricity } \\
\hline & & & & \multirow{2}{*}{$\begin{array}{c}\text { Transmission } \\
\text { System Usage } \\
\text { Charge (USD/kWh) }\end{array}$} & \multirow{2}{*}{$\begin{array}{c}\text { Public Service } \\
\text { Charge } \\
\text { (USD/kWh) }\end{array}$} & & & \multicolumn{6}{|c|}{$\begin{array}{l}\text { Charge for Base Power in Its Distribution } \\
\text { Component (USD/kWh) * }\end{array}$} \\
\hline & & & & & & & & 1 & 2 & 3 & 4 & 5 & 6 \\
\hline Arica & StxA-1-A & Aerial & 1.35 & 0.02 & 0.0006 & 0.096 & 0.023 & 0.037 & 0.037 & 0.037 & 0.037 & 0.037 & 0.037 \\
\hline Arica & StxA-1-S1 & Underground. 1 & 1.35 & 0.02 & 0.0006 & 0.096 & 0.023 & 0.047 & 0.047 & 0.047 & 0.047 & 0.047 & 0.047 \\
\hline Arica & StxA-1-S2 & Underground. 2 & 1.35 & 0.02 & 0.0006 & 0.096 & 0.023 & 0.043 & 0.043 & 0.043 & 0.043 & 0.043 & 0.043 \\
\hline Arica & StxA-1-S3 & Underground. 3 & 1.35 & 0.02 & 0.0006 & 0.096 & 0.023 & 0.053 & 0.053 & 0.053 & 0.053 & 0.053 & 0.053 \\
\hline Camarones & StxA-1-A & Aerial & 1.35 & 0.02 & 0.0006 & 0.086 & 0.023 & 0.037 & 0.037 & 0.037 & 0.037 & 0.037 & 0.037 \\
\hline
\end{tabular}

Note. * Segmentation of residential customers, according to average monthly energy consumption of the previous year: 1: less than or equal to $200 \mathrm{kWh}, 2$ : greater than $200 \mathrm{kWh}$ and less than or equal to $210 \mathrm{kWh}, 3$ : greater than $210 \mathrm{kWh}$ and less than or equal to $220 \mathrm{kWh}$, 4: greater than $220 \mathrm{kWh}$ and less than or equal to $230 \mathrm{kWh}, 5$ : greater than $230 \mathrm{kWh}$ and less than or equal to $240 \mathrm{kWh}$, 6: greater than $240 \mathrm{kWh}$ 


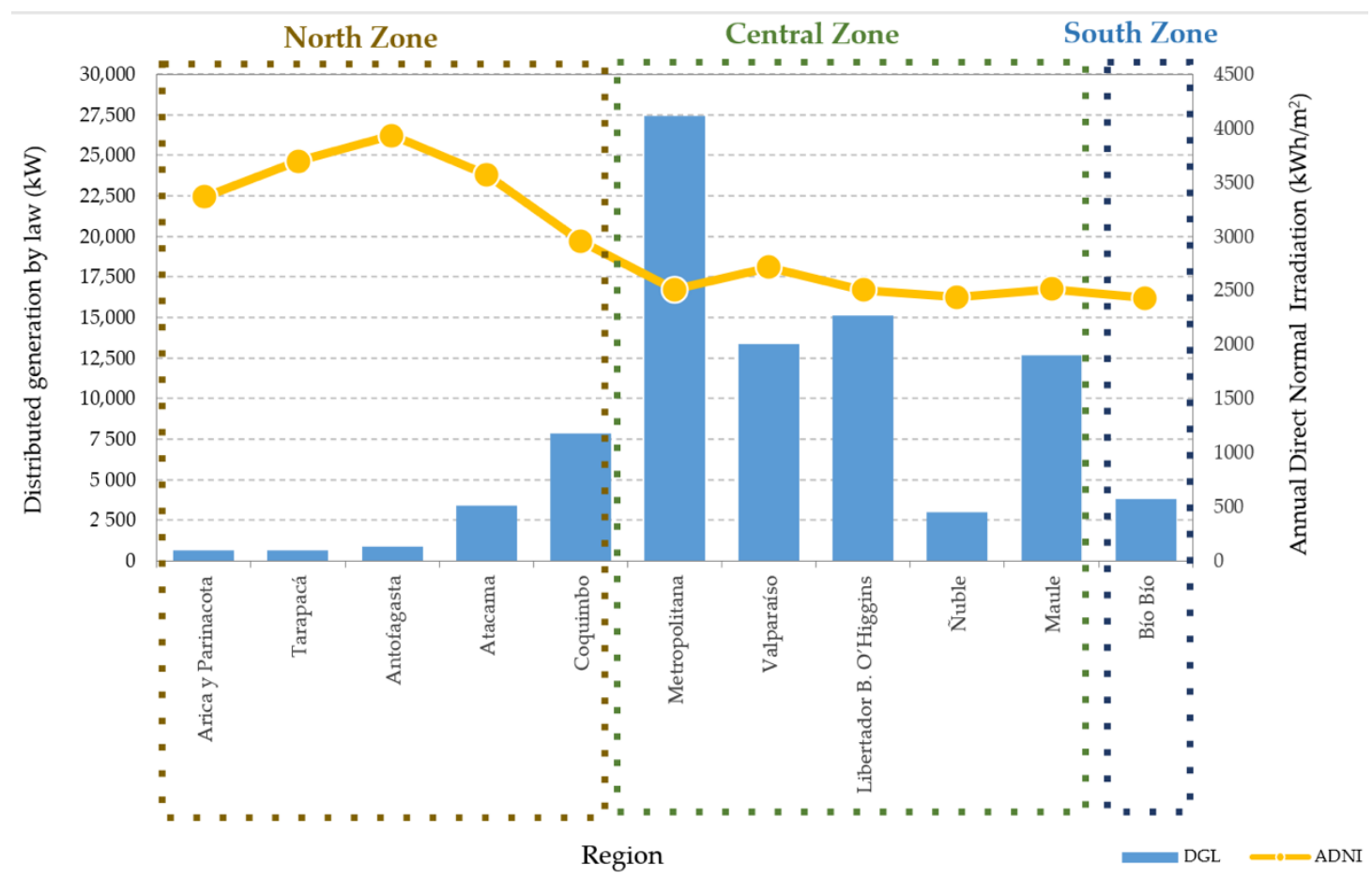

Figure 7. Comparative graph of Ley de Generación Distribuida and Annual Normal Irradiation by region. Prepared by the authors.

\subsubsection{Cases of Public Distribution}

To date there are only six projects of public and private institutions, developed in the city of Arica, which were reported to the SEC. The first solar roof project was carried with private funds, by the company Neumatrix in 2015. Through the Public Solar Roofs Program, solar roof initiatives have been financed for: Teleton Foundation, Hospital Regional de Arica and Parinacota Dr. Juan Noé, Liceo Politécnico Antonio Varas de la Barra and Liceo Politécnico de Arica. The Pablo Neruda High School Project was carried out with mixed financing, with contributions from the Luksic Foundation and the Municipality of Arica. All these projects have completed the procedures and connection permits, which correspond to a form to regularize installations connected to the grid through an On-Grid system [44], before the Superintendencia de Electricidad y Combustible, under Law No. 20571.

There are also private initiatives, such as the projects promoted by SERC Chile's Ayllu Solar initiative, where photovoltaic fields have been enabled and implemented: "Enabling an on-grid system in photovoltaic plant and energy management program, Altos de Azapa", and "River shrimp farming through the intensive use of solar energy for the sustainable development of the town of Camarones" [45].

\section{Case Studies and Projections}

\subsection{Current and Projected Energy Consumption in the City of Arica}

To account for electricity consumption in the city of Arica, as an example, the consumption of 16 customers was monitored randomly (Figure 8) for a period of three years; 2018 to 2020. Its geographical location is represented in the following satellite map:

Using data from the electricity consumption of 16 clients under study, a graph was made to show that both client 11 and 12 represent the highest and lowest total electricity consumption during the 36-month period. The results are displayed in Figure 9.

From the electricity consumption data recorded in the period 2018-2020, the maximum, minimum and average values for each customer were subtracted (Figure 10). It can be observed that the box and whiskers plot of the average consumption has a slightly larger range than that of the minimum consumption. A greater dispersion can be observed in the 
second quartile, while in quartiles 3 and 4 there is a clear concentration of data, which is more reliable when choosing data within this quartile to use as a reference for this study.

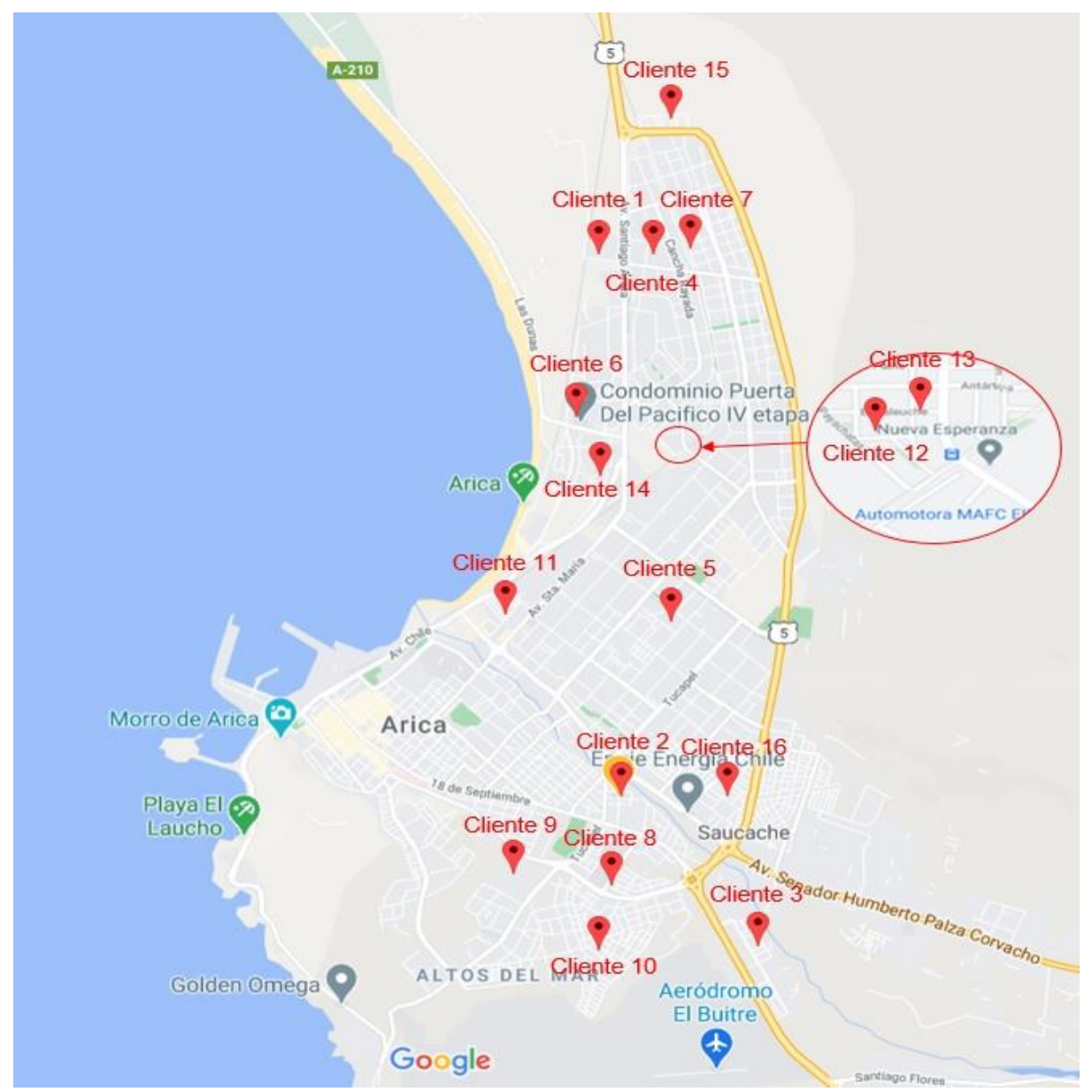

Figure 8. Satellite image of the terrestrial location of clients under study. Source: [46].

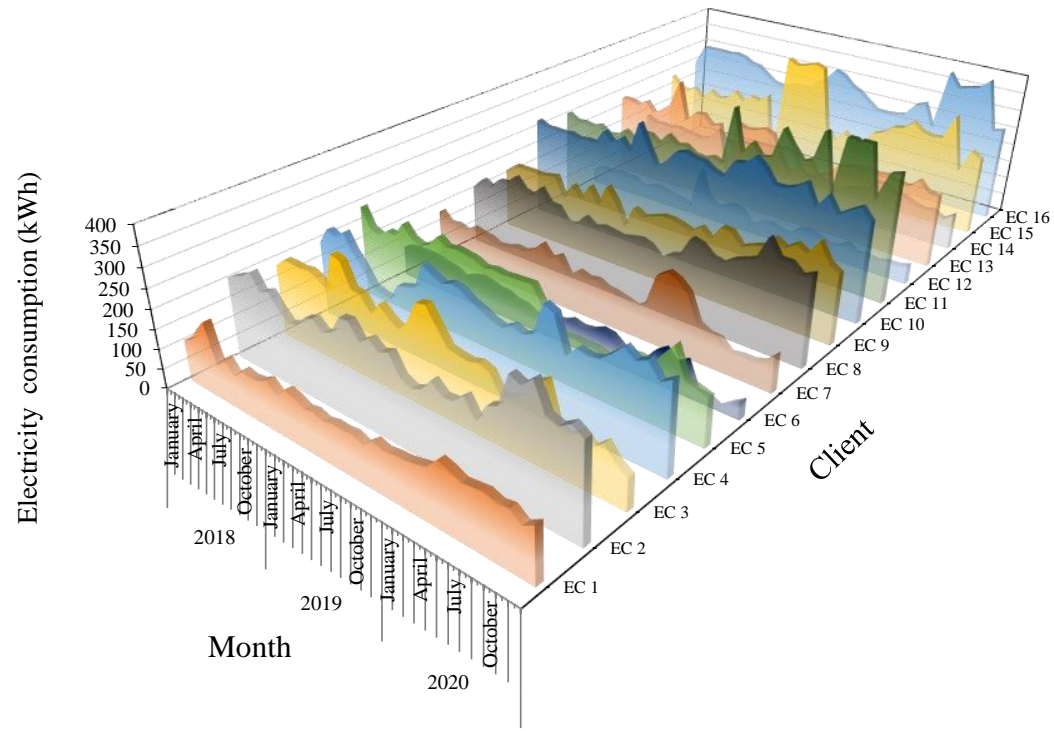

Figure 9. Electricity consumption by client. Arica: January 2018 to December 2020 (Source: Prepared by the authors). 


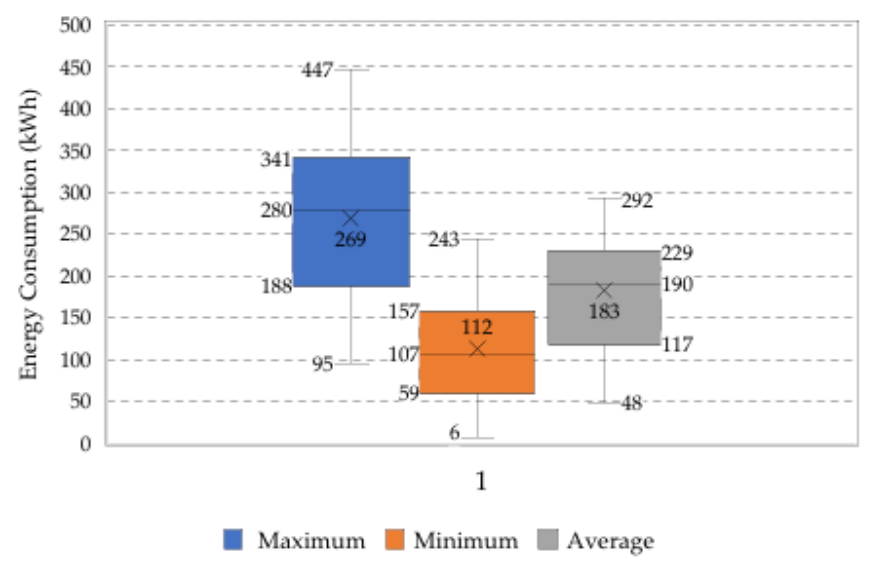

Figure 10. Box-and-whisker plot of maximum, minimum and average monthly residential energy consumption by client under study for the period 2018-2020 (Source: Prepared by the authors).

Subsequently, from the average consumption data, the respective consumption and projection graph can be obtained (Figure 11).

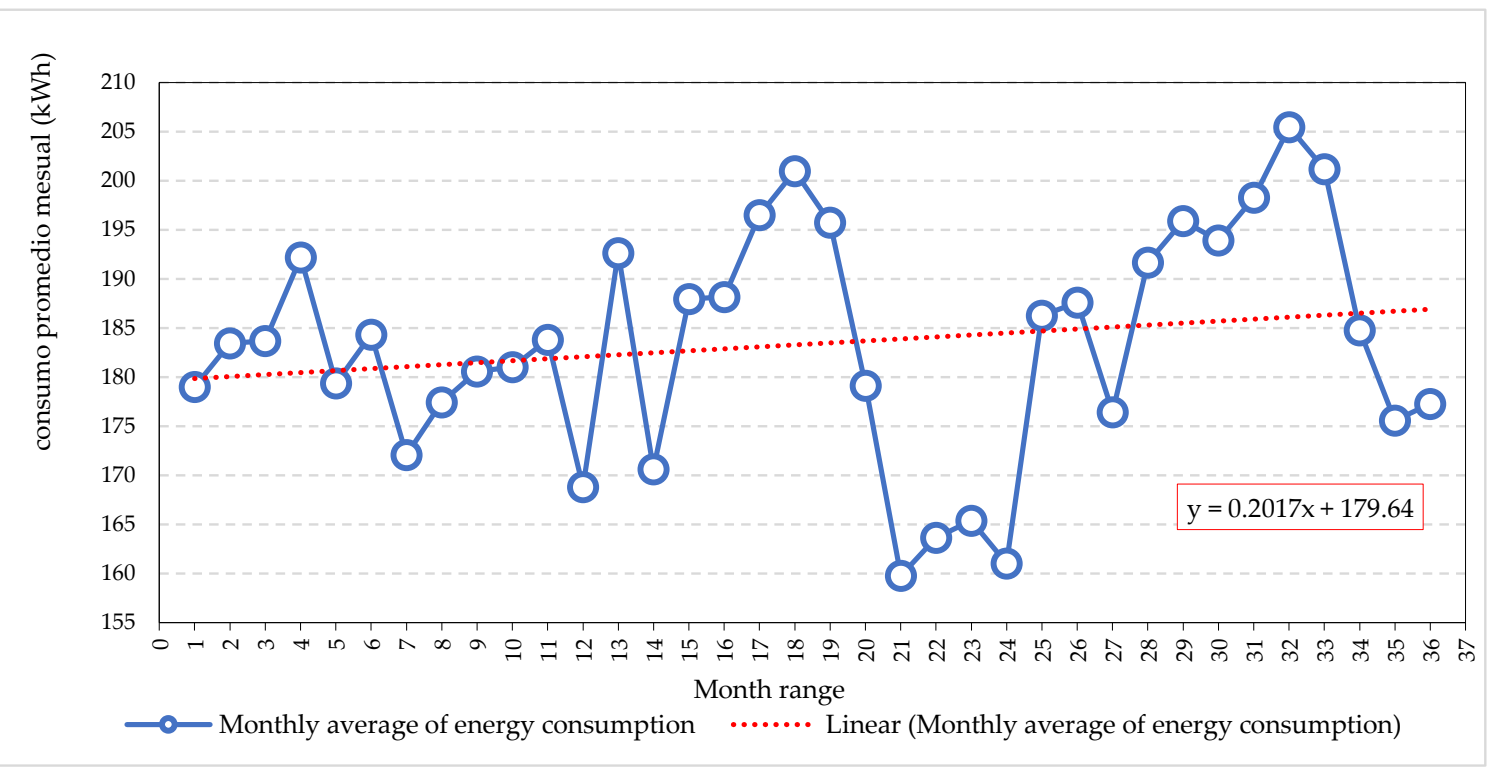

Figure 11. Monthly averages of energy consumption of all clients for the period 2018-2020. Note. January 2018 (range 1); December 2020 (range 36) (Source: Prepared by the authors).

The range from 1 to 36 months is associated to January 2018 and December 2020 respectively. Therefore, if we consider the same logic in the future, from January 2018 to January 2050, 396 months (33 years) will have passed. In this sense, by 2050, the average monthly residential consumption based on the linear consumption trend function in Figure 10 will be $259.5 \mathrm{kWh}$.

According to the National Energy Commission [5] for the region of Arica and Parinacota during 2020, the average annual energy consumption was $180 \mathrm{kWh} /$ year. This value could represent the consumption of a family of 3 to 4 members. Therefore, if the annual energy consumption continues to grow until reaching $259.5 \mathrm{kWh}$ by 2050, it will have increased by approximately $41.5 \%$ compared to year 2020 . This also depends to a large extent on the evolution and efficiency of technologies that will exist in homes, since they could consume less electricity. Although the price of electricity for each year depends on the type of residential consumption, the BT1 tariff (associated to all the customers under study) is the simpler tariff [43]. BT1 tariff only measures the energy consumed and there is no direct charge for the power demanded. 
The final composition of electricity bills has a common structure, in which six main charges stand out (See Table 3):

- $\quad$ Service administration: Fixed monthly charge BT1 (USD/client)

- Electricity transport (USD/kWh): Transmission system use charge, Public service charge, Energy charge, Power purchase charge

- Charge for electricity consumed: Charge for base power in its distribution component (USD/kWh)

The tariff charges for electricity consumed for a BT1 customer correspond to:

$$
\text { BT1 tariff charge }=\text { Electricity transport }+ \text { Charge for electricity consumed }
$$

While, to obtain the final charge for electricity consumed $(\mathrm{kWh})$ reflected in the electricity bills, the following equation can be carried out:

$$
\begin{aligned}
\text { Billing for Tariff } & \text { Charges BT1 } \\
& =\text { Service administration } \\
& +(\text { Electricity transport }+ \text { Charge for electricity consumed }) \\
& * \text { Electricity consumption by client }
\end{aligned}
$$

It is worth mentioning that, since this article defines $2018-2020$ as the study period, the projection for 2050 may be affected by Law No. 21185 [5] and its tariff adjustment. This last can be seen in the following graph.

According to this study and Figure 10, the charge for electricity consumed in the electricity billing would include a discount for the injection of electricity to the grid and it is estimated that from 2018 to 2020 this discount may represent $43.9 \%$ on average of the invoice charge corresponding to the month in which such injections were made.

Therefore, considering the above, for the year 2050 and according to the linear trend equations in Figure 12, it was calculated that the tariff for electricity consumption and injection to the grid will be 0.542 (USD/kWh) and 0.244 (USD $/ \mathrm{kWh}$ ), respectively (that is if Law No. 21185 remains active until 2050 and allows a stabilized tariff). Finally, it is estimated that the tariff for electricity consumption and sale of energy by injection to the grid, from 2018 to 2050, will have increased by $103.38 \%$ and $91.40 \%$, respectively.

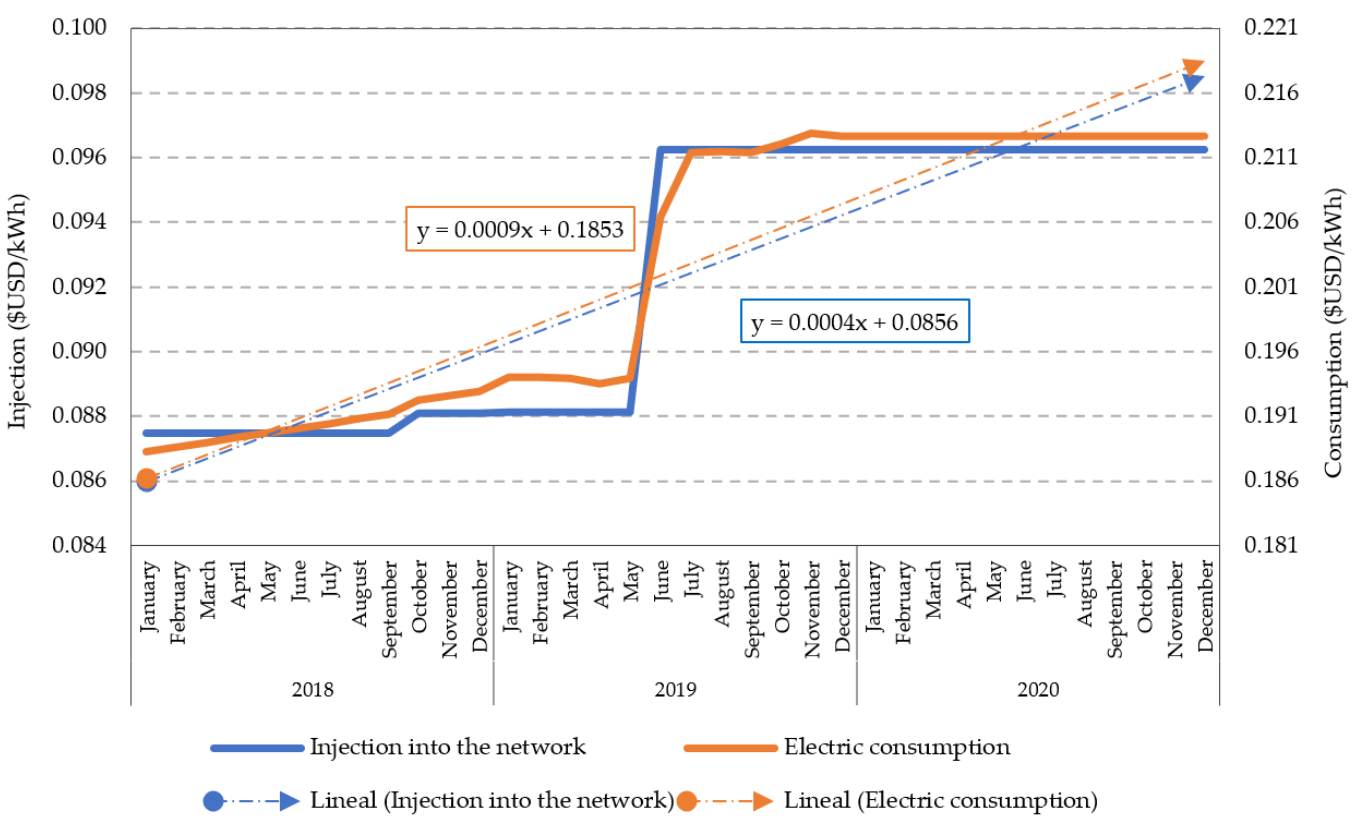

Figure 12. Electric energy consumption and injection to the network tariffs of Arica for 2018-2021. These rates are present on the official site of the distribution company CGE, where they are broken down into various items. Source: Adapted from [43]. 


\subsection{Uncertainties}

For long-term projections, there are various uncertainties that may impact our projections. A central element is the cost trend of generation technologies and storage systems. Key to this are the LCOE projections for solar and storage technologies (Lithium batteries and hydrogen based storage). Further, there is a growing electrification of consumption for cooking, heating and transportation purposes. This may have a direct influence on the increase in per capita consumption in the region. Finally, according to climate change trends, solar radiation in the coastal areas of Arica and Parinacota may be affected downwards [47]. Consequently, the use of solar systems would be expected to be displaced a few kilometers inland. This could affect the level of electricity injection at the household level in the coastal zone.

\subsection{Projection of Electricity and Economic Demand in the Region of Arica and Parinacota to 2050}

In the Region of Arica and Parinacota, there are 300 clear days per year, with an average daily solar radiation of $7.15 \mathrm{kWh} / \mathrm{m}^{2}$, conditions that would allow a home to have a photovoltaic installation of $1 \mathrm{~kW}$. If we consider an installation of these characteristics for each of the 61,782 homes in the region (with an assumption of four subjects per home), we would obtain a total installed household capacity of $62 \mathrm{MW}$. Such capacity would help the population to be self-sufficient in terms of electricity. Furthermore, the estimate of available potential in the region, considering a projection of 42,958 MW, could turn Arica and Parinacota into an exporter of electric energy to both Chile and South America.

Finally, they mention that $128 \mathrm{GWh}$ of electricity corresponds to the regional consumption of residential customers and it translates into approximately $6 \mathrm{kWh}$ of average daily consumption per household [48].

\subsubsection{Electricity Demand Projection for 2050}

Through the Carbon Neutrality Plan, which seeks to decarbonize the electricity matrix via the exit of coal-fired power plants and the incorporation of more renewable energy. Here, an important factor is considered to evaluate the projection for 2050 for the injection of distributed electricity in the region of Arica and Parinacota, Chile. To evaluate the incentive of energy use at residential level, the LEAP model adapted by the Centro de Energía of the Universidad de Chile is used. This is a software tool widely used for energy policy analysis and climate change mitigation assessment. That is, LEAP allows policy analysts to create and evaluate alternative medium- and long-term scenarios, comparing energy needs, costs, social benefits and environmental impact [22] (LEAP, 2020).

In order to create a projection of the region, a simulation of residential energy demand from 2017 to 2050 was carried out for sectors such as industrial, mining, and residential, among others (Table 4).

Based on the obtained results, the residential demand data was plotted, showing that there is a projection of $315 \mathrm{GWh}$ to 2050. From 2020 to 2050, residential energy demand is expected to increase by more than $200 \%$. As an example; residential electricity consumption per customer is currently $2160 \mathrm{kWh}$ /year in the region, and it is assumed that this value remains constant for the year 2050. In addition, it is considered that in that year a total of 145,833 customers would require electricity (190\% of the current number of customers). This would imply a significant increase in the number of customers producing their own electricity, based on renewable energies or efficient cogeneration, and thus being able to sell their surplus generation to the distribution network. 
Table 4. Projected electricity demand in the region of Arica and Parinacota for different sectors 2017 to 2050 (GWh).

\begin{tabular}{|c|c|c|c|c|c|c|c|c|c|c|c|c|c|c|c|c|c|}
\hline Year & 2017 & 2018 & 2019 & 2020 & 2021 & 2022 & 2023 & 2024 & 2025 & 2026 & 2027 & 2028 & 2029 & 2030 & 2031 & 2032 & 2033 \\
\hline Industry & 78 & 77 & 77 & 77 & 78 & 78 & 79 & 80 & 80 & 81 & 82 & 82 & 83 & 83 & 84 & 84 & 84 \\
\hline Mining & 21 & 22 & 22 & 22 & 23 & 23 & 23 & 23 & 24 & 24 & 24 & 25 & 25 & 25 & 25 & 26 & 26 \\
\hline Transportation & 0 & 0 & 0 & 4 & 8 & 11 & 15 & 18 & 22 & 30 & 39 & 49 & 61 & 74 & 93 & 115 & 115 \\
\hline Residential & 137 & 142 & 147 & 151 & 156 & 160 & 164 & 168 & 172 & 177 & 181 & 186 & 191 & 196 & 201 & 207 & 207 \\
\hline Commercial & 90 & 91 & 94 & 98 & 104 & 110 & 116 & 122 & 128 & 135 & 141 & 149 & 156 & 164 & 171 & 179 & 179 \\
\hline Public & 20 & 21 & 22 & 22 & 22 & 22 & 22 & 24 & 25 & 27 & 28 & 30 & 31 & 33 & 34 & 36 & 37 \\
\hline Total & 345 & 354 & 362 & 374 & 390 & 404 & 420 & 436 & 453 & 474 & 497 & 522 & 548 & 576 & 611 & 648 & 648 \\
\hline Year & 2034 & 2035 & 2036 & 2037 & 2038 & 2039 & 2040 & 2041 & 2042 & 2043 & 2044 & 2045 & 2046 & 2047 & 2048 & 2049 & 2050 \\
\hline Industry & 85 & 85 & 85 & 85 & 85 & 85 & 85 & 86 & 86 & 86 & 87 & 87 & 88 & 89 & 89 & 90 & 91 \\
\hline Mining & 26 & 27 & 27 & 27 & 28 & 28 & 28 & 29 & 29 & 29 & 30 & 30 & 30 & 31 & 31 & 31 & 32 \\
\hline Transportation & 169 & 203 & 238 & 290 & 348 & 410 & 472 & 530 & 598 & 671 & 759 & 857 & 963 & 1088 & 1233 & 1382 & 1558 \\
\hline Residential & 220 & 227 & 234 & 241 & 248 & 254 & 260 & 266 & 272 & 277 & 283 & 288 & 293 & 298 & 304 & 309 & 315 \\
\hline Commercial & 196 & 205 & 213 & 223 & 232 & 242 & 252 & 262 & 273 & 283 & 294 & 305 & 316 & 328 & 340 & 352 & 364 \\
\hline Public & 40 & 42 & 43 & 46 & 48 & 49 & 51 & 52 & 55 & 56 & 58 & 61 & 62 & 64 & 67 & 68 & 70 \\
\hline Total & 736 & 788 & 840 & 912 & 988 & 1068 & 1149 & 1224 & 1313 & 1404 & 1511 & 1629 & 1754 & 1897 & 2064 & 2233 & 2430 \\
\hline
\end{tabular}




\subsubsection{Economic Projection for 2050}

The economic evaluation of the installation of a solar generation system is very important for the user, since it will determine whether the project is convenient and economically viable or not. The life of a photovoltaic generation system is usually between 20 and 25 years, however, an evaluation horizon of 30 years and a discount rate of $10 \%$ will be considered-a widely accepted value for evaluating projects. In order to perform a 2050 economic analysis, hours of peak energy demand in a house should be considered, around hours 19 to 23, while photovoltaic power generation occurs between 12 and $16 \mathrm{~h}$ approximately. Therefore, the occurrence of demand and generation do not coincide throughout the day. On the one hand, this time discrepancy means that there will be hours in which surplus energy will be injected into the grid, while there will be others in which more energy will be consumed than generated. On the other hand, this section compares the data according to the theoretical and simulated data. For this purpose, the performance and financial model (Figure 13) that fits the PV system (Solar Photovoltaic System) residential On-Grid under study (connected to the grid) is selected with the use of the System Advisor Model (SAM) software [18], as shown below:

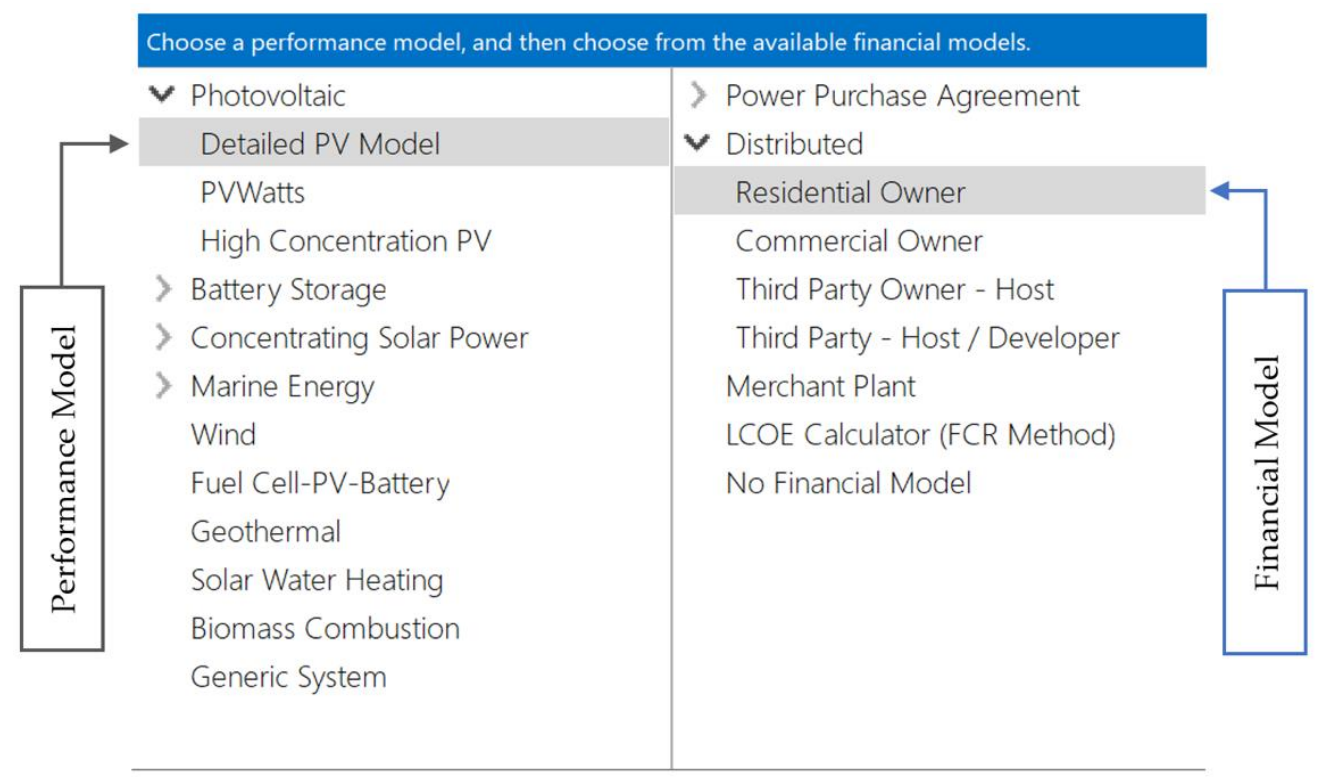

Figure 13. Performance and financial model selected for the study. Source: [18].

For this purpose, the following characteristics are simulated:

All data from the solar resource explorer and meteorological data in CSV format are entered in SAM corresponding to the average client [21].

- $\quad$ Technical details of polycrystalline solar module KYL-30P

- $\quad$ SUN2000L-2KTL Inverter Technical Details

- $\quad$ System Design (Azimuth $=0$, Inclination $=20$, Module Area $=11.2 \mathrm{~m}^{2}$ )

- Lifetime and Degradation (total annual AC production of the system is $0.5 \%$ /year, typical for PV)

SAM provides the categories under Direct Capital Costs and Indirect Capital Costs at convenience and to aid track project installation costs.

Therefore, the following costs associated with the PV are designated and replaced in the cost system section of SAM:

- $\quad$ Solar module cost: USD 127.1, VAT included [49]

- $\quad$ Inverter cost: USD 1262.4, VAT included [50]

- $\quad$ Estimated cost for installation of the PV system structure: USD 184.4 [51], VAT included 
Costs associated with the field are not taken into account, since the PV system is installed within the same residence.

The operation and maintenance (O\&M) costs must include the complete maintenance of the PV system (solar modules, inverter, structure, wiring system, etc.) and must be performed every 6-12 months. Therefore, there are several prices that comply with the respective maintenance in Chile and that can have the following exemplary values: First, a monthly cleaning of the panels being the owner of the PVS able to perform it at USD 12; Second, change of the inverter equivalent to its cost (between 10 to 17 years) in case the product no longer works (within the warranty); and, Third, replacement of damaged modules according to cost per module at year 25 (limit year of operation of the typical solar module). Further, the estimated cost associated with electronic equipment, electrical materials and others corresponds to $28 \%$ of the total investment cost for installations below $300[\mathrm{kWp}][52]$.

On the one hand, from the simulation performed in SAM it is possible to obtain different results (Table 5), both on performance and finance. The first result was a summary list and description of the most important variables contained in a metric table:

Table 5. Summary of metric values associated with the PV under study.

\begin{tabular}{ll}
\hline \multicolumn{1}{c}{ Metric } & \multicolumn{1}{c}{ Value } \\
\hline Annual energy (Year 1) & $3831 \mathrm{kWh}$ \\
Capacity factor (Year 1) & $22.0 \%$ \\
Energy yield (Year 1) & $1931 \mathrm{kWh} / \mathrm{kW}$ \\
Performance Ratio (Year 1) & 0.81 \\
Nominal levelized cost of energy & $0.0555 \mathrm{USD} / \mathrm{kWh}$ \\
(nominal LCOE) & $0.0417 \mathrm{USD} / \mathrm{kWh}$ \\
Actual levelized cost of energy (actual LCOE) & USD 187 \\
Electric bill without system (year 1) & USD -78 \\
Electric bill with system (year 1) & USD 265 \\
Net savings with system (year 1) & USD 399 \\
Net present value (NPV) & 10 years and 9 months (Approximately in \\
Simple payback period & 11 years) \\
Discounted payback period & NaN \\
Net capital cost & USD 2209 \\
Capital & USD 0 \\
Debt & USD 2209 \\
\hline
\end{tabular}

Note. USD (United States dollar). Source: Adapted from simulation in SAM.

On the other hand, for the (real) LCOE value associated with the design PV, which was 41,685 USD/MWh, a comparison can be drawn with common LCOE values associated with PV On-Grid at residential level [53].

It should be noted that Table 6 shows values for the first year of study: electricity bill without PV, with it and net savings with PV, as shown in the following table:

Table 6. Results of the SAM factoring.

\begin{tabular}{|c|c|}
\hline Financial Parameters & $\begin{array}{c}\text { American Dollars } \\
\text { (USD) }\end{array}$ \\
\hline Bill without PV (year 1) (FL $\mathrm{BPV}$ ) & 187 \\
\hline Bill with PV (year 1) (FLWPV) & $(-) 78$ \\
\hline Net savings with the system (year 1) & 265 \\
\hline
\end{tabular}

The first year's cost of purchasing electricity from an electricity service provider is calculated for two scenarios. One with and another without the renewable energy system. 
Later on, net savings are calculated as the difference between the two. SAM assumes the same electricity load and electricity tariff structure for both scenarios. Likewise, for the first year the PV allowed saving up to $100 \%$ of the debt and generated a surplus of $26.2 \%$ of the cost of the electricity bill without PV.

The following table shows all the bills evaluated by SAM projected for 2050 starting in 2020 (Table 7):

Table 7. Electricity bills for the residence under study with and without the use of PV on Grid for the period 2021-2050.

\begin{tabular}{|c|c|c|}
\hline Year & $\begin{array}{l}\text { Bill without PV } \\
\text { (USD) }\end{array}$ & $\begin{array}{l}\text { Bill with PV } \\
\text { (USD) }\end{array}$ \\
\hline 2021 & 187.1 & $(-) 78.0$ \\
\hline 2022 & 193.1 & $(-) 78.5$ \\
\hline 2023 & 199.3 & $(-) 79.0$ \\
\hline 2024 & 205.7 & $(-) 79.4$ \\
\hline 2025 & 212.3 & $(-) 79.8$ \\
\hline 2026 & 219.1 & $(-) 80.2$ \\
\hline 2027 & 226.1 & $(-) 80.5$ \\
\hline 2028 & 233.3 & $(-) 80.7$ \\
\hline 2029 & 240.8 & $(-) 80.9$ \\
\hline 2030 & 248.5 & $(-) 81.1$ \\
\hline 2031 & 256.5 & $(-) 81.2$ \\
\hline 2032 & 264.7 & $(-) 81.3$ \\
\hline 2033 & 273.2 & $(-) 81.2$ \\
\hline 2034 & 282.0 & $(-) 81.2$ \\
\hline 2035 & 291.0 & $(-) 81.0$ \\
\hline 2036 & 300.3 & $(-) 80.8$ \\
\hline 2037 & 309.9 & $(-) 80.5$ \\
\hline 2038 & 319.9 & $(-) 80.1$ \\
\hline 2039 & 330.1 & $(-) 79.6$ \\
\hline 2040 & 340.7 & $(-) 79.0$ \\
\hline 2041 & 351.6 & $(-) 78.4$ \\
\hline 2042 & 362.9 & $(-) 77.6$ \\
\hline 2043 & 374.5 & $(-) 76.7$ \\
\hline 2044 & 386.5 & $(-) 75.7$ \\
\hline 2045 & 398.9 & $(-) 74.6$ \\
\hline 2046 & 411.7 & $(-) 73.4$ \\
\hline 2047 & 424.9 & $(-) 72.0$ \\
\hline 2048 & 438.5 & $(-) 70.5$ \\
\hline 2049 & 452.6 & $(-) 68.8$ \\
\hline 2050 & 467.1 & $(-) 67.0$ \\
\hline$\Sigma$ & $9.203,0$ & $(-) 2338.7$ \\
\hline
\end{tabular}

Note. "(-)" indicates that the electricity bill for the respective year has already been paid and it is the customer's profit from the surplus electricity sold to the grid. Source: Adapted from simulation in SAM.

It is expected that by the year 2050, the PV will be able to supply the entire annual demand of the average customer under study (USD 9203) and, consequently, the customer will obtain an additional profit of USD 2339 at the end of the project. Therefore, by using the VFS, net savings reach approximately USD 11,542 (equivalent to 5.2 times the investment capital of the system [USD 2209]).

In summary, through the financial results modeled with SAM for 2050's projection, the following observations can be considered (Figure 14): 

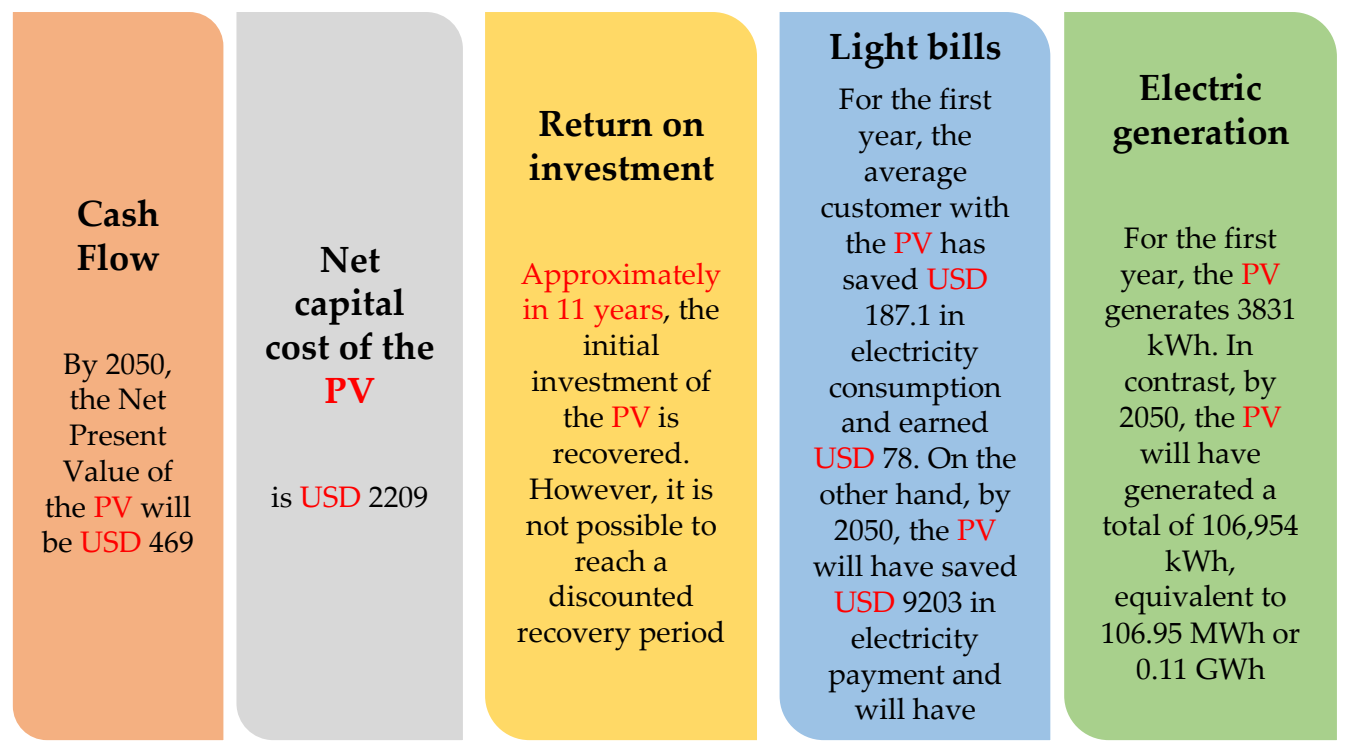

Figure 14. Financial results in SAM of the PV under study. Source: Adapted from simulation in SAM.

A SAM simulation result, complementary to the previous ones, is the Sankey diagram for the analysis of the energy system. The diagram allows differentiating the energy at different points in the system and the source of energy losses at each point. In addition, this diagram serves as a complementary tool to study the results obtained from the integrated evaluation model that was used in the present investigation. For the photovoltaic system, the following percentages of energy loss were obtained according to the source as a result of the simulation:

- Nominal Energy of the plane of the array (POA): 27,936 (kWh). The percentage of energy loss are: $0 \%$ shading, $5 \%$ Soiling and $2.542 \%$ Reflection;

- Nominal DC Energy: $4398(\mathrm{kWh})$. The percentage of energy loss are: $0 \%$ Snow, $6.34 \%$ Module deviation from STC (standard test conditions), $0 \%$ Inverter MPPT clipping, $2 \%$ Module mismatch, $0.5 \%$ Diodes and connections, $2 \%$ DC wiring, $0 \%$ Tracking error, $0 \%$ Nameplate, $0 \%$ DC power optimizer, $0 \%$ DC availability and curtailment, and $0 \%$ DC Lifetime daily losses- year one;

- Net DC energy: $3937(\mathrm{kWh})$. The percentage of energy loss are: $0 \%$ Inverter power clipping, $0 \%$ Inverter power consumption, $0.11 \%$ Inverter nighttime consumption, and $1.601 \%$ Inverter efficiency;

- Gross AC energy: 3869 (kWh). The percentage of energy loss are: 1\% AC wiring, $0 \%$ AC Lifetime daily losses; year one, $0 \%$ Transformer loss, $0 \%$ AC Availability and curtailment, $0 \%$ Grid interconnection limit;

- Annual energy (kWh): 3830.

Losses represent the performance reduction not explicitly calculated by the PVWatts model of the same software. SAM applies the total system losses to the AC output power calculated by the model.

\section{Discussion and Comments}

Through this work a fresh vision is obtained regarding the applicability of Ley $\mathbf{N}^{\mathbf{o}}$ 20.571 de Generación Distribuida en casas residenciales (Distributed Generation in residential houses), considering as an example the case of the city of Arica, located in the region of Arica and Parinacota in Chile. Its solar potential is of utmost consideration and also a projection on its integration to residences from here to 2050. A large residential demand is estimated with $315 \mathrm{GWh}$ in the region of Arica and Parinacota for that year.

Regarding the results of economic projection in SAM for 2050, it was gathered that: the PV will have a profit of USD 469 according to the NPV; net capital cost is equivalent to 2209 USD; Approximately in 11 years the initial investment of the PV is recovered; during 
the first year the customer with the PV has saved USD 187.1 in electricity consumption and has earned USD 78, whilst by 2050 the PV will have saved USD 9203 in electricity bill payments allowing a USD 2339 profit; and finally, in the first year the PV will generate 3831 kWh, but by 2050 it will have generated 13.5\% less electricity ( $3311 \mathrm{kWh}$ ) and will have accumulated a total of $106,954 \mathrm{kWh}$ (equivalent to $106.95 \mathrm{MWh}$ or $0.11 \mathrm{GWh}$ ) during the 2020-2050 period.

On the other hand, under the context of Energy Losses, after running the simulation it was possible to appreciate the effect of these losses on the results (21.087\% of energy loss), where the main factors (ordered from greater to lesser importance) are: Deviation of the STC module (standard test conditions), dirt of the photovoltaic modules (Soiling effect), reflection of photovoltaic modules, mismatch of the photovoltaic module, DC wiring, decrease in inverter efficiency, AC wiring, diodes and connections, and night consumption of the inverter.

According to all of the above, an evaluation on the applicability of Law No. 20571 in the city of Arica is performed through the identification of existing barriers and opportunities (Table 8).

Table 8. Identification of the barriers and opportunities related to the applicability of Law No. 20571 in Arica.

\begin{tabular}{cc}
\hline Barriers & Opportunities \\
\hline $\begin{array}{c}\text { Lower price of electricity generated by } \\
\text { households covered by Law No. 20571, with a } \\
\text { value almost 50\% lower than the value applied } \\
\text { by electric companies to their } \\
\text { regulated customers. }\end{array}$ & $\begin{array}{c}\text { Solar potential of the sector, better } \\
\text { than worldwide. }\end{array}$ \\
\hline $\begin{array}{c}\text { High initial investment costs, considering the } \\
\text { GDP of the region of Arica and Parinacota, } \\
\text { which translates into financial barriers. }\end{array}$ & $\begin{array}{c}\text { Desert climate, sunny days almost all } \\
\text { year round. }\end{array}$ \\
\hline $\begin{array}{c}\text { Lack of offers. There are few companies that } \\
\text { offer services of photovoltaic panels } \\
\text { installations at residential level. }\end{array}$ & $\begin{array}{c}\text { Duty-free zone, which allows tax benefits for } \\
\text { the development of this type of solution. }\end{array}$ \\
\hline
\end{tabular}

\section{Conclusions}

We can gather that in relation to the effectiveness of Law No. 20571-regarding the incentive for users to self-generate their own electricity through the installation of photovoltaic panels, i.e., for home distributed generation-it should be considered that the region, despite having an extraordinary solar potential worldwide, is not enough to massify this solution mainly in the homes of the northern area.

We hope that this work will be a contribution to Chile's public policies, considering not only the solar potential of the sector but also evaluating aspects such as the socio-economic reality and the specific signals required by each region: campaigns, financial incentives, creation of critical mass of suppliers, among others.

As future work we consider the need for a systematic systematic analysis of uncertainties in order to identify different vulnerabilities, scenarios and strategies. The objective is to be able to make recommendations on robust public policies in the face of the recognized uncertainties.

Finally, a review of existing public policies, improving aspects such as the purchase and sale price of electricity from solar energy, encouraging the community to apply these regulations in their homes is proposed.

Author Contributions: The author's contributions are: writing-original draft preparation, C.M.-C., L.C.-P. and P.V.-S.; Conceptualization, A.Z., C.M.-C., E.E. and R.P.-B.; Validation R.P.-B.; Visualization, E.E.; writing E.E. and L.C-P.-Revision and Edition. Methodology C.M.-C. and P.V.-S., and software, H.T.-C. and R.P.-B. All authors have read and agreed to the published version of the manuscript. 
Funding: This research was funded by Solar Energy Research Center, SERC-Chile grant number (ANID/FONDAP/15110019) and Project UTA-Mayor grant number 8748-20. Reviewers are thanked for their valuable comments on the manuscript.

Institutional Review Board Statement: Not applicable.

Informed Consent Statement: Not applicable.

Data Availability Statement: Not applicable.

Acknowledgments: The authors wish to thank the support of the Project UTA Mayor N ${ }^{\circ} 8748-20$ and Solar Energy Research Center, SERC-Chile (FONDAP / ANID/15110019).

Conflicts of Interest: The authors declare no conflict of interest.

\begin{tabular}{|c|c|}
\hline \multicolumn{2}{|c|}{ Abbreviations } \\
\hline \multicolumn{2}{|c|}{ The following abbreviations are used in this manuscript: } \\
\hline $\mathrm{AC}$ & Alternating current \\
\hline & It is the base monomic electricity tariff in Chile for household customers at low \\
\hline BT1 & $\begin{array}{l}\text { voltage (BT: baja tensión). } \\
\text { Compañía General de Electricidad Industrial S.A, electric company of the city of }\end{array}$ \\
\hline CGE & Arica, Chile. \\
\hline $\mathrm{CNE}$ & Comisión Nacional de Energía (National Energy Commission) \\
\hline CSV & Comma-Separated Value format \\
\hline DGL & Distributed Generation Law \\
\hline FLBPV & Bill without PV \\
\hline FLWPV & Bill with PV \\
\hline GDP & Gross domestic product \\
\hline GHG & Greenhouse Gas \\
\hline LCOE & Levelized Cost of Energy \\
\hline LEAP & Long-Range Energy Alternatives Planning System \\
\hline Mini-Hydro & Mini-hydraulic power plant \\
\hline $\mathrm{NaN}$ & Not a Number \\
\hline NCRE & Non-Conventional Renewable Energies \\
\hline NPV & Net present value \\
\hline OECD & Organization for Economic Co-operation and Development \\
\hline O\&M & Operation and Maintenance \\
\hline PV system & Solar Photovoltaic System \\
\hline SAM & System Advisor Model \\
\hline SERC-Chile & Chilean Solar Energy Research Center \\
\hline PV & System Photovoltaic \\
\hline & Superintendencia de Electricidad y Combustibles (Superintendency of \\
\hline SEC & Electricity and Fuels) \\
\hline VAT & Value Added Tax \\
\hline
\end{tabular}

\section{References}

1. Banco Mundial. Energía. Panorama General. 2018. Available online: https://www.bancomundial.org/es/topic/energy/ overview (accessed on 3 June 2021)

2. Naciones Unidas. Goal 7. Ensure Access to Affordable, Reliable, Sustainable and Modern Energy for All. Sustainable Development Goals; División de Estadística de las Naciones Unidas (UNSD): New York, NY, USA, 2021. Available online: https: / / unstats.un.org/ sdgs/report/2019/goal-07/ (accessed on 5 April 2021).

3. Banco Mundial. Datos. Producción de Electricidad a Partir de Fuentes de Petróleo, Gas y Carbón (\% del Total). Grupo Reporte Mundial. 2019. Available online: https:/ / datos.bancomundial.org/indicator/EG.ELC.FOSL.ZS?end=2015\&start=1960 (accessed on 10 January 2021).

4. Kibria, A.; Sherzod, B.; Akhundjanov, S.B.; Oladi, R. Fossil fuel share in the energy mix and economic growth. Int. Rev. Econ. Financ. 2019, 59, 253-264. [CrossRef]

5. NDC. Contribución Determinada a Nivel Nacional de Chile. 2020. Available online: https://mma.gob.cl/wp-content/uploads/ 2020/04/NDC_Chile_2020_espan\%CC\%83ol-1.pdf (accessed on 15 April 2021).

6. Ministerio de Energía. Energía 2050, Política Energética de Chile; Ministerior de Energía: Santiago, Chile, 2015; p. 46. Available online: http:/ / www.energia.gob.cl/sites/default/files/energia_2050_-_politica_energetica_de_chile.pdf (accessed on 10 February 2021). 
7. Simsek, Y.; Lorca, A.; Urmee, T.; ABahrid, P.; Escobar, R. Review and assessment of energy policy developments in Chile. Energy Policy 2019, 127, 87-101. [CrossRef]

8. Gobierno de Chile. Estrategia Nacional de Energía, 2012-2030. Energía para el futuro. Available online: https://mma.gob.cl/wpcontent/uploads/2014/10/3_Estrategia-Nacional-de-Energia-2012-2030_Energia-para-el-Futuro.pdf (accessed on 2 June 2021).

9. Ministerio de Economía, Fomento y Reconstrucción. Ley Ernc 20.257. Introduce Modificaciones a la Ley General de Servicios Eléctricos Respecto de la Generación de Energía Eléctrica con Fuentes de Energías Renovables no Convencionales; Ministerio de Economía, Fomento y Reconstrucción: Santiago, Chile, 2008. Available online: https:/ / www.bcn.cl/leychile/navegar?idNorma=270212\&idVersion= 2013-10-22\&idParte $=8021629$ (accessed on 25 September 2021).

10. Comisión Nacional de Energía. Energia Abierta. Cumplimiento de Ley ERNC 20.257. 2021. Available online: http://datos. energiaabierta.cl/dataviews/92666/cumplimento-de-ley-ernc-20257/ (accessed on 25 September 2021).

11. Cornejo, L.; Martín-Pomares, L.; Alarcón, D.; Blanco, J.; Polo, J. A Through analysis of solar irradiation measurements in the region of Arica Parinacota, Chile. Renew. Energy 2017, 112, 197-208. [CrossRef]

12. Cornejo-Ponce, L.; Moraga-Contreras, C.; Vilca-Salinas, P. Analysis of Chilean legal regime for brine obtained from desalination processes. Desalination Water Treat. 2020, 203, 91-103. [CrossRef]

13. Haas, J.; Palma-Behnke, R.; Valencia, F.; Araya, P.; Díaz-Ferrána, G.; Telsnigc, T.; Eltrop, L.; Díaz, M.; Püschela, S.; Grandel, M.; et al. Sunset or sunrise? Understanding the barriers and options for the massive deployment of solar technologies in Chile. Energy Policy 2018, 112, 399-414. [CrossRef]

14. Solargis. Solar Resource Maps of Chile. Irradiación Directa Normal de Chile. (c) 2019 The World Bank, Source: Global Solar Atlas 2.0, Solar resource data: Solargis. 2019. Available online: https://solargis.com/es/maps-and-gis-data/download/world (accessed on 10 February 2021).

15. CNE. Comisión Nacional de Energía. Reporte Mensual; CNE: Santiago, Chile, 2021; Volume 60. Available online: https://www. cne.cl/wp-content/uploads/2021/08/RMensual_ERNC_v202108.pdf (accessed on 25 September 2021).

16. Instituto Nacional de Estadística. Comuna de Camarones. Región de Arica y Parinacota. Resultados Censo 2017; Instituto Nacional Estadistica: Santiago, Chile, 2017. Available online: http:/ / resultados.censo2017.cl/Region?R=R15 (accessed on 10 May 2020).

17. Ministerio de Energía. Energía Región. Resumen de Estadísticas Energéticas. 2019. Available online: https://www.energiaregion. cl/dashboardregional/XV (accessed on 20 September 2021).

18. SAM. System Advisor Model. General Description. 2021. Available online: https://www.nrel.gov/docs/fy18osti/70414.pdf (accessed on 10 February 2021).

19. Dobos, A.; Neises, T.; Wagner, M. Advances in CSP Simulation Technology in the System Advisor Model. Energy Procedia 2014, 49, 2482-2489. [CrossRef]

20. Ministerio de Energía. Ley 20.571: Regula el Pago de las Tarifas Eléctricas de Las Generadoras Residenciales; Congreso Nacional de Chile (National Congress of Chile): Santiago, Chile. Available online: https:/ / www.leychile.cl/Navegar?idNorma=1038211 (accessed on 5 January 2021).

21. Ministerio de Energía. Explorador Solar. 2021. Available online: https://solar.minenergia.cl/exploracion (accessed on 10 February 2021).

22. LEAP. Introduction. 2020. Available online: https://leap.sei.org/default.asp?action=introduction (accessed on 20 February 2021).

23. Global Climate Risk Index 2017. Germanwatch. Available online: https:/ / www.germanwatch.org/es/12978 (accessed on 20 February 2021).

24. Nicole, T. Chile se Encuentra Entre Los Diez Países Más Afectados Por el Cambio Climático en 2015, Universidad de Chile. 2016. Available online: http:/ / www.uchile.cl/noticias/128419/chile-entre-los-diez-paises-mas-afectados-por-el-cambio-climatico (accessed on 10 February 2021).

25. Selvam, K.; Kumar, D.M.V.; Siripuram, R. Distributed Generation Planning using Peer Enhanced Multi-objective TeachingLearning based Optimization in Distribution Networks. J. Inst. Eng. 2016, 98, 203-211. [CrossRef]

26. Minsiterio de Energía. Decreto 57, 2020. Aprueba Reglamento de Generación Distribuida Para Autoconsumo; Minsiterio de Energía: Santiago, Chile, 2020. Available online: https: / / www.bcn.cl/leychile/navegar?idNorma=1149788\&idParte=10161866\&idVersion=20 20-11-06 (accessed on 10 March 2021).

27. Vita, V.; Ekonomou, L.; Christodoulou, C. The impact of distributed generation to the lightning protection of modern distribution lines. Energy Syst. 2016, 7, 357-364. [CrossRef]

28. Ministerio de Energía. Agenda de Energía-Un Desafío País, Progreso Para Todos. 2014. Available online: http:/ / www.energia. gob.cl/sites/default/files/agenda_de_energia_-_resumen_en_espanol.pdf (accessed on 10 February 2021).

29. Ministerio de Energía. Ley N $\mathrm{N}^{\mathrm{2}}$ 20.698. Propicia la Ampliación de la Matriz Energética, Mediante Fuentes Renovables No Convencionales. Available online: https:/ / www.leychile.cl/Navegar?idNorma=1055402 (accessed on 10 February 2021).

30. Ministerio de Energía. Programa de Techos Solares Públicos. 2020. Available online: http://www.minenergia.cl/techossolares/ ?page_id=33 (accessed on 10 February 2021).

31. BCN. Biblioteca del Congreso Nacional de Chile. Historia de la Ley N ${ }^{o}$ 20.571. Regula el Pago de Las Tarifas Eléctricas de Las Generadoras Residenciales; Primer Trámite Constitucional: Senado, Chile, 2020. Available online: //www.bcn.cl/historiadelaley/ nc/historia-de-la-ley/vista-expandida/4547/\#h2_1_1 (accessed on 10 February 2021). 
32. Ministerio de Economía, Fomento y Reconstrucción. Ley 20.257: Introduce modificaciones a la Ley General de Servicios Eléctricos Respecto de la Generación de Energía Eléctrica con Fuentes de Energías Renovables no Convencionales; Congreso Nacional de Chile (National Congress of Chile): Santiago, Chile, 2013. Available online: https:/ / www.bcn.cl/leychile/navegar?idNorma=270212 \&idVersion=2013-10-22\&idParte $=$ (accessed on 10 September 2021).

33. Ministerio de Energía. Ley N ${ }^{\circ}$ 21.118: Modifica la Ley General de Servicios Eléctricos, Con el Fin de Incentivar el Desarrollo de Las Generadoras Residenciales. 2018. Available online: https:/ / www.leychile.cl/Navegar?idNorma=1125560 (accessed on 10 February 2021).

34. OECD/IEA. Global Energy and CO2 Status Report. The Latest Trends in Energy and emissions in 2018. 2018. Available online: https: / / www.iea.org/geco/ (accessed on 25 May 2019).

35. REN21. Renewable Now. 2019. Available online: https://www.ren21.net/gsr-2019/chapters/chapter_01/chapter_01/ (accessed on 10 February 2021).

36. IRENA. Trends in Renewable Energy. International Renewable Energy Agency. 2021. Available online: https://www.irena.org/ Statistics/View-Data-by-Topic/Capacity-and-Generation/Statistics-Time-Series) (accessed on 23 September 2021).

37. CNE. Comisión Nacional de Energía. Reporte Mensual ERNC; CNE: Santiago, Chile, 2020; Volume 46, p. 5. Available online: https://www.cne.cl/wp-content/uploads/2020/06/RMensual_ERNC_v202006.pdf (accessed on 25 September 2021).

38. Energia Abierta; Comisión Nacional de Energía. Dashboard región. 2021. Available online: https://energiaregion.cl/ dashboardregional/I (accessed on 25 September 2021).

39. Emol. Mapa: Cuánto Cuesta la Energía Eléctrica de Uso Residencial en Chile y el Mundo. 2017. Available online: https://www. emol.com/noticias/Economia/2017/07/19/867452/Mapa-Cuanto-cuesta-la-energia-electrica-en-el-mundo.html (accessed on 25 September 2021).

40. SEC. Resumen Mensual de la Industria Energetica, Informe SEC, Agosto 2021. Super Intendencia de Electricidad y Combustible, SEC. 2021. Available online: https://www.sec.cl/sitio-web/wp-content/uploads/2021/09/Informe-SEC-Agosto-2021.pdf (accessed on 25 September 2021).

41. Almusaied, Z.; Asiabanpour, B.; Aslan, S. Optimization of Solar Energy Harvesting: An Empirical Approach. J. Sol. Energy. 2018, 2018, 9609735. [CrossRef]

42. Parrado, C.; Girard, A.; Simon, F.; Fuentealba, E. 2050 LCOE (Levelized Cost of Energy) projection for a hybrid PV (photovoltaic)CSP (concentrated solar power) plant in the Atacama Desert, Chile. Energy 2016, 94, 422-430. [CrossRef]

43. CGE. Tarifa de Suministro. 2021. Available online: https://www.cge.cl/informacion-comercial/tarifas-y-procesos-tarifarios/ tarifa-de-suministro/ (accessed on 27 December 2021).

44. Energía Abierta. Datos Que Consideran Las Instalaciones Declaradas Ante la SEC Mediante el Trámite eléctrico TE4, Región de Arica y Parinacota. 2021. Available online: https:/ / energiaregion.cl/region/AyP (accessed on 25 September 2021).

45. Proyecto Ayllu Solar. Iniciativa SERC Chile. 2021. Available online: www.ayllusolar.cl (accessed on 25 September 2021).

46. Google Maps. Búsqueda de Arica y Parinacota. Arica, Chile. Available online: https://www.google.cl/maps/place/Arica, +Arica+y+Parinacota/@-18.4723921,-70.3242532,13z/data=!3m1!4b1!4m5!3m4!1s0x915aa98ad932c235:0x27f5886c04d8d71d! 8m2!3d-18.4782534!4d-70.3125988 (accessed on 19 April 2021).

47. Palma-Behnke, R.; Abarca del Río, R.; Agostini, C.; Alvear, C.; Amaya, J.; Araya, P.; Arellano, N.; Arriagada, P.; Avilés, C.; Barría, C.; et al. The Chilean Potential for Exporting Renewable Energy; Mitigation and Energy Working Group Report; Comité Científico de Cambio Climático; Ministerio de Ciencia, Tecnología, Conocimiento e Innovación: Santiago, Chile, 2021.

48. La fuerza del Sol. $2^{\circ}$ Edición. ISBN: 978-956-393-154-9. Available online: http://ayllusolar.cl/wp-content/uploads/2020/03/ LIBRO_LA_FUERZA_DEL_SOL.pdf (accessed on 10 February 2021).

49. Kuhn, Panel Solar Fotovoltaico Policristalino 330 WATTS KYL-330P KUHN. Available online: https://www.kuhn.cl/webstore/ energiasolar/fotovoltaica/panelsolar/panel-solar-fotovoltaico-policristalino-330-watts-kyl-330p-kuhn.html (accessed on 5 May 2021).

50. Solarstore. Estructuras de montaje. Kit Montaje 6 Paneles 1 Fila Coplanar. Available online: https://www.solarstore.cl/producto/ kit-estructura-soporte-montaje-6-paneles-1-fila-co (accessed on 5 May 2021).

51. Solarstore. Inversores on Grid. Obtenido de Inversor on Grid 2 kw HUAWEI Certificado SEC. Available online: https://www. solarstore.cl/producto/inversor-huawei-on-grid-2kw-huawei/ (accessed on 5 May 2021).

52. Echile. (diciembre de 2019). Programa de Energías Renovables y Eficiencia Energética en Chile. Obtenido de Índice de Precios Fotovoltaico v2019. Available online: https:/ / 4echile-datastore.s3.eu-central-1.amazonaws.com/wp-content/uploads/2020/08/ 03195541/Factsheet-IP-FV_menor-resoluci\%C3\%B3n_Final.pdf (accessed on 23 December 2021).

53. Lazard. Levelized Cost of Energy and Levelized Cost of Storage-2020. Obtenido de View the Full Levelized Cost of Energy Report. 2020. Available online: https://www.lazard.com/media/451419/lazards-levelized-cost-of-energy-version-140.pdf (accessed on 10 February 2021). 